\author{
A dissertation submitted to the faculty of \\ as San Francisco State University \\ In partial fulfillment of \\ 2014 \\ EDD \\ The Requirements for \\ The Degree \\ .566 \\ Doctor of Education \\ In \\ Educational Leadership
}

by

Alexander R. Jones

San Francisco, California

August 2019 


\section{CERTIFICATION OF APPROVAL}

I certify that I have read The Effects of Career-Readiness Programming on the Employment Outcomes of Sonoma State Alumni by Alexander Ronald Jones, and that in my opinion this work meets the criteria for approving a dissertation submitted in partial fulfillment of the requirements for the degree: Doctor of Education in Educational Leadership at San Francisco State University.

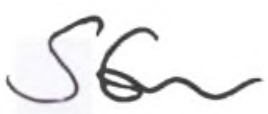

Sheldon, Gen, Ph.D.

Associate Professor

San Francisco State University

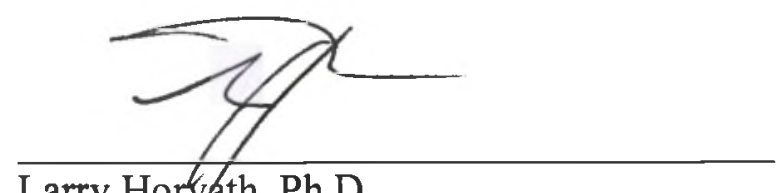

Larry Hortath, Ph.D.

Associate Professor

San Francisco State University

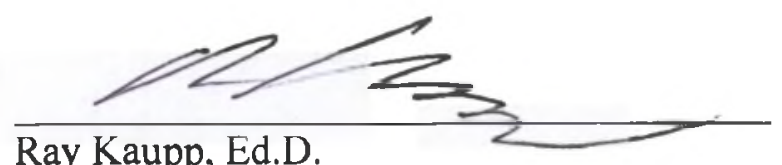

Adjunct Faculty

San Francisco State University 


\title{
THE EFFECTS OF CAREER-READINESS PROGRAMMING ON THE EMPLOYMENT OUTCOMES OF SONOMA STATE UNIVERSITY ALUMNI
}

\author{
Alexander R. Jones \\ San Francisco State University \\ 2019
}

The purpose of this case study was to assess whether the Heuristic Model of Employability when paired with career-related programming, services and work-based learning activities produced equitable employment outcomes for Sonoma State University alumni. In addition, this case study sought to determine whether alumni of color and women participated in career-related programming and activities at the same rates as their counterparts. Quantitative data revealed that alumni who utilized career fairs, career-readiness workshops and work-based learning activities required less time to secure full-time positions after graduation. Data also showed that female respondents participated in work-based learning activities at higher rates than male respondents, male respondents utilized career-readiness workshops at higher rates than female respondents, and there was no statistical significance indicating whether alumni of color utilized career-related services at lower rates than white respondents. The data from this case study reveal the importance of career services' programming (i.e. one-on-one advising, career-readiness workshops and career fairs) and work-based learning opportunities (i.e. internships) on the employment outcomes of graduates. The lack of career readiness programming within higher education institutions is an educational inequity. All students should have equitable access to career-related co-curricular activities, only then will graduates possess the requisite skills needed to navigate the workforce and find their "best fit" careers.

I certify that the Abstract is a correct representation of the content of this dissertation.

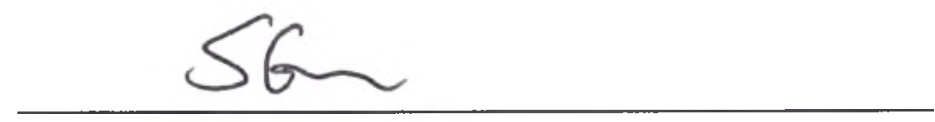

Chair, Dissertation Committee

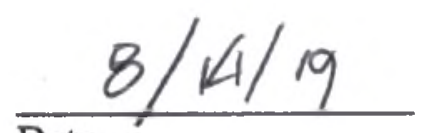

Date 


\section{ACKNOWLEDGEMENTS}

My journey during this program has been full of surprises, but I made it! I first would like to thank my mother Alice Cheng who passed away in 2011 , and my father Dr. Ronald Wendell Jones who passed away while I was in this program. I learned that this doctorate and many things in my life were within my reach from them both. I would like to thank my Uncle Gary and Uncle Calvin for supporting and encouraging me during this process and in life. I would like to thank my friends

who I have known for over 20 years for providing me with perspective and knowledge, even though I may not have shown them appreciation for it. I would like to Samyalisa Enright for her love, continuous support, encouragement, insight, and for making me a better person. I would like to thank Sheldon Gen, Larry Horvath, Ray Kaupp, and the "Get it Done" crew for guiding and supporting my educational experience, I will not let you down! 


\section{TABLE OF CONTENTS}

List of Tables ...........................................................................................................ii

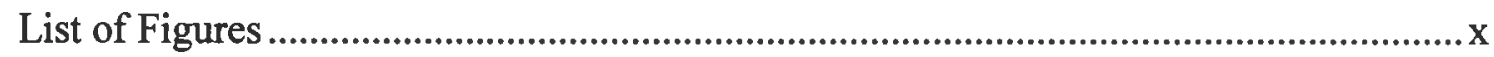

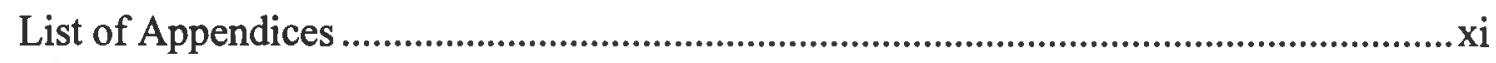

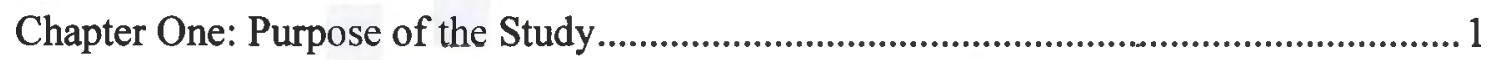

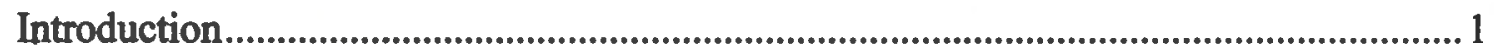

Purpose of the Study ……............................................................................................ 1

Research Questions and Design....................................................................................4

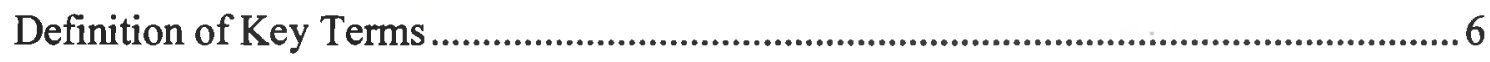

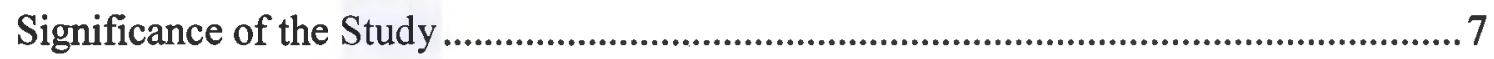

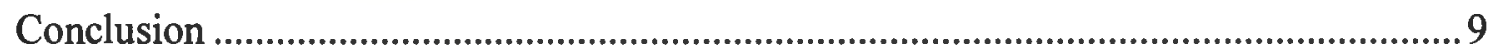

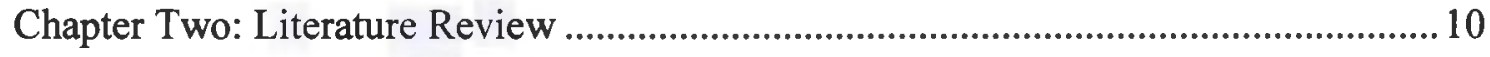

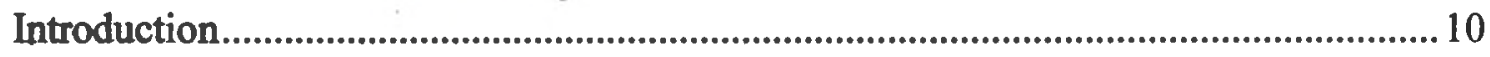

Conceptual Framework ..................................................................................................... 10

Employability and the Heuristic Model of Employability ................................................ 12

Career Identity and the Heuristic Model of Employability ............................................. 12

Social and Human Capital and the Heuristic Model of Employability ............................ 16

Personal Adaptability and the Heuristic Model of Employability ....................................19

Race, Gender, Ethnicity and Employment..........................................................................2

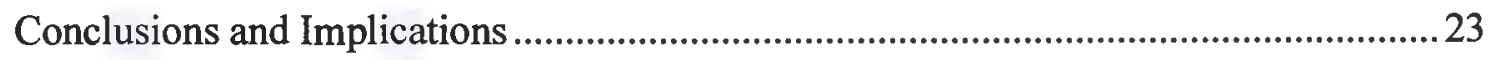

Chapter Three: Methodology .........................................................................................2.

Research Design and Role of Researcher .......................................................................25 


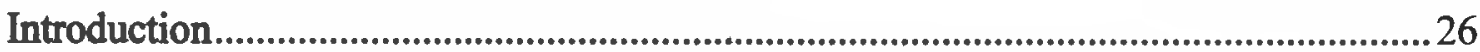

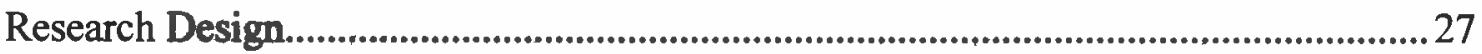

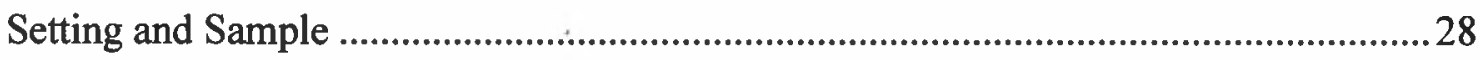

Ethics and Protection of Human Subjects.......................................................................30

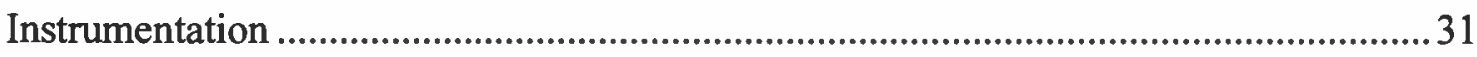

Data Collection and Analysis......................................................................................................... 34

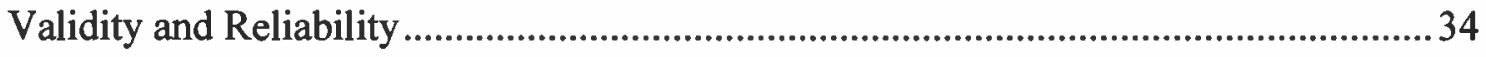

Chapter Four: Report of Findings ................................................................................... 36

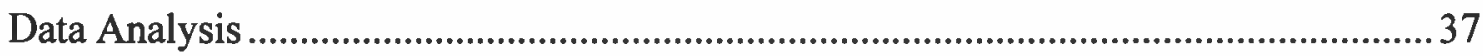

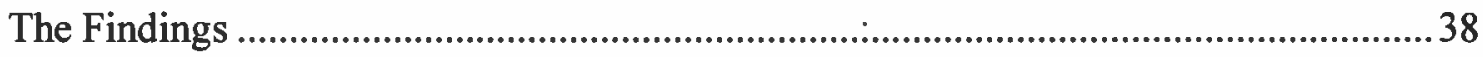

Summary and Synthesis ............................................................................................51

Chapter Five: Discussion and Recommendations..............................................................55

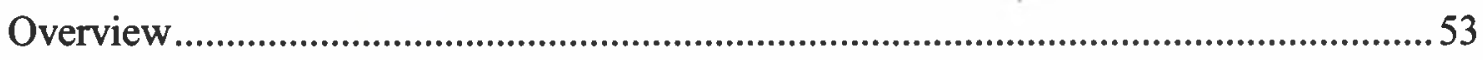

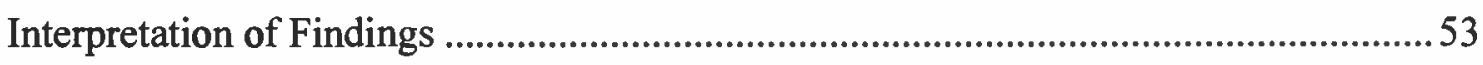

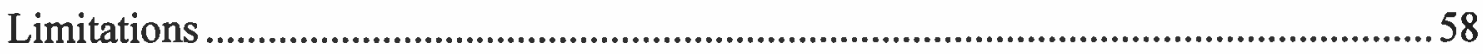

Implications....................................................................................................................5

Recommendations for Action ........................................................................................6 62

Recommendations for Further Study ...........................................................................63

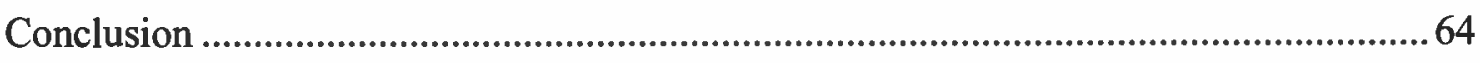

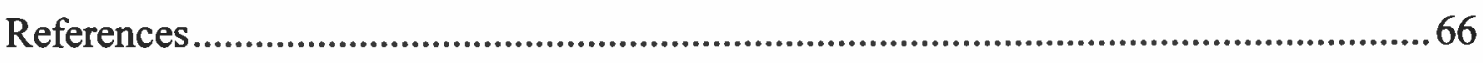

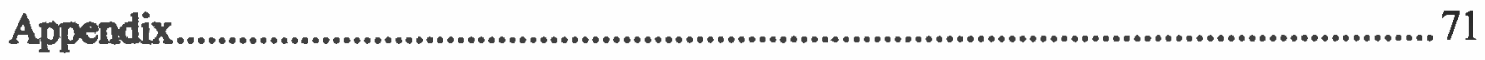




\section{LIST OF TABLES}

Table 1. Survey Respondent and SSU Gender Identity .............................................. 29

Table 2. Racial/Ethnic Identity of Survey Respondents and SSU Students ................... 30

Table 3. Research Variable Definition................................................................................ 33

Table 4. Conceptual Variables, Demographics and their Operationalization.................. 37

Table 5. Employment Grouping for SSU Alumni ............................................................. 39

Table 6. Chi- Square Analyses of Career-Related Programming Participants,

Work-Based Learning Activity Participants and the Employment Grouping .................. 40

Table 7. Months it Took Internship Participants to Secure Full-Time Employment

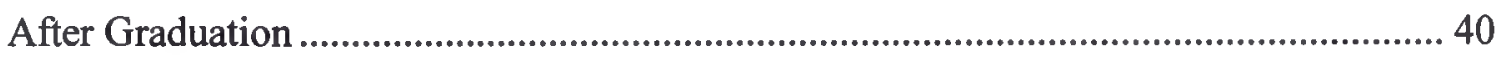

Table 8. Months it Took Career-Readiness Workshop Participants to Secure Full-

Time Employment after Graduation for .......................................................................... 41

Table 9. Months it Took Career-Related Programming and Work-Based Learning

Activities to Secure Full-Time Employment After Graduation......................................... 41

Table 10. Chi- Square Analyses of Career-Related Programming Participants,

Work-Based Learning Activity Participants and the Employment Grouping .................. 42

Table 11. Chi- Square Analyses of Career-Related Programming Participants,

Work-Based Learning Activity Participants and the Employment Grouping .................. 43

Table 12. Months it Took Internships and Career-Readiness Workshop

Participants to Secure Full-Time Employment After Graduation ..................................... 44

Table 13. Number of Months it Took Internship and Informational Sessions 
Participants to Secure Full-Time Emploment After Graduation 44

Table 14. Number of Months it Took Internship and Advising Participants to

Secure Full-Time Emploment After Graduation 45

Table 15. Number of Months it Took Internship and Career Fair Participants to

Secure Full-Time Emploment After Graduation 45

Table 16. T-Test Analyses of Career-Related Programming Participants, Work-

Based Learning Activity Participants and Months it Took SSU Alumni to

Secure Full-Time 46

Table 17. Gender and Employment Outcomes ................................................................... 49

Table 18. Gender and Career-Readiness Participation ..................................................... 48

Table 19. Gender and Advising Participation..............................................................49

Table 20. Gender and Informational Sessions Participants ............................................ 49

Table 21. Gender and Internship Participants................................................................ 50

Table 22. Gender and Service Learning Participants ...................................................... 51

Table 23. Internship and Career-Related Programming, and Months Required to

Secure Full-Time Positions After Graduation 54 


\section{LIST OF FIGURES}

Figure 1. Heuristic Model of Employability from Employability: A Psycho-social Construct Its Dimensions and Applications by Fugate, 2004, Journal of Vocational

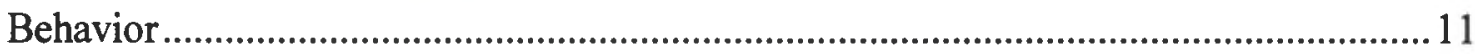




\section{LIST OF APPENDICES}

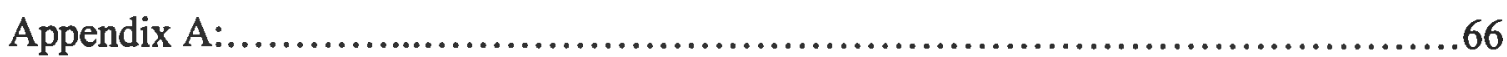

Appendix B: CTEOS Survey ...................................................67

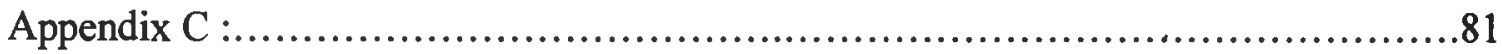




\section{CHAPTER ONE: PURPOSE OF THE STUDY}

\section{Introduction}

This dissertation examines how participation in career readiness programming within a California State University (CSU) supported the employment outcomes of alumni. According to a UCLA annual national survey conducted by the Higher Education Research Institute (HERI, 2016), 84.8\% of entering four-year college students indicated that "being able to get a job" was a very important reason for attending college, and $72.6 \%$ indicated that "making more money" was another very important reason to attend college. While these numbers have dropped ( $2 \%-3 \%$ over the past six years), employability outcomes still play a significant role for students when deciding to pursue a postsecondary degree.

\section{Purpose of the Study}

The California State University system (CSU) was created in 1960 under the California Master Plan for Higher Education. The CSU's mission is to not only advance and extend knowledge through undergraduate and graduate degrees offerings, but to provide opportunities for individuals to develop intellectually, personally, and professionally; while preparing significant numbers of educated, responsible people to contribute to California's schools, economy, culture, and future, and ensure that the quality of teaching is preparing job-ready graduates ("The California State University," 2019). 
While the CSU system has successfully created initiatives that eliminate opportunity and achievement gaps and created opportunities for students to graduate in a timely manner, research has shown that higher education current initiatives and programming have been ineffective in preparing students for their roles within the workforce. A study conducted by the McKinsey Center for Government (2012) analyzed 100 education to employment initiatives in 25 countries, surveyed more than 8,000 youth, education providers, and employers in nine countries. Results from this study highlighted that $58 \%$ of employers believed their recent hires were not adequately prepared by their pre-hire education for an entry-level position, $55 \%$ of youth felt they were not adequately prepared for an entry-level position in their chosen career field, $50 \%$ of surveyed youth believed their post-secondary education had improved their chances of securing employment, and $72 \%$ of education providers believed their graduates were adequately prepared for an entry-level position. In another study conducted by Gallup (2017), 96\% of chief academic officers of colleges and universities believed that their institutions were very or somewhat effective at preparing students for the workforce; while only $11 \%$ of business leaders strongly agreed to this notion. Research has identified a disconnect between how students, employers and higher education institutions view college graduates' preparation for the workforce.

One implication of this misalignment is a persistent skills gap in which college graduates lack the abilities that companies need and value (Gallup, 2017). According to 
the National Association of College Employers (NACE, 2018), employers indicated that in addition to good GPA, they were also seeking evidence of vocational (i.e., work experience or hands on instruction) and professional attributes (i.e. communication skills, team-work, professionalism, etc.) from new hires. When deciding on two equally qualified candidates, (a) completion of an internship with the same organization, (b) internship experience in similar industries, (c) major, (4) held leadership positions, (5) general work experience and (6) high GPA were heavily favored (in this order). Lastly, extracurricular activities, school attended, volunteer work, fluency in a foreign language and studying abroad had little to no influence on their hiring decisions (NACE, 2018). Another explanation for this employability disconnect can be attributed to students not accessing career center resources and work-based learning opportunities that are designed to support employability upon graduation. Research has shown that nearly four in ten students have never visited their school's career services office or used online career resources, $35 \%$ of seniors say they have never used this resource, and of those who did, they were just as likely to say their experience with career services was not at all helpful as they were to say it was very helpful $-16 \%$ each (Gallup, 2017). Career centers within higher education institutions are designed to support the career development, career preparation and marketability of students to employers. When students do not utilize these career services' resources, they are unaware of industry required skillsets, and continue to contribute to the disconnect within the education to employment pipeline. 
CSU campuses must begin analyzing best practices that have contributed to higher employability outcomes for their graduates; with the goal replicating these resources and programming for future students.

\section{Research Questions and Design}

A quantitative case study with Sonoma State University (SSU) alumni respondents was used to examine the following research questions:

1. How did career services' resources, programming and work-based learning activities support the employability of SSU alumni?

2. How are career services' resources, programing and work-based learning activities providing equitable employment outcomes for all recipients?

3. How are career services' resources, programing and work-based learning activities being utilized by women and students of color compared to their white male counterparts?

Sonoma State University (SSU) is a liberal arts college located in Rohnert Park, CA approximately 50 miles from San Francisco, CA. SSU provides services for 9300 students and has 41 majors. SSU was an appropriate research site for various reasons. First, SSU is a campus that is part of the California State University (CSU) system, which is the largest public university system in the U.S (480,000 students total across 23 campuses). The goal of this case study is to provide insight and best practices for SSU, the CSU system and students enrolled in one of the other 22 CSU campus; especially 
since all CSU campuses have the same CSU Chancellor Office mission and vision around student preparation. Second, SSU's Career Center prior to 2019, has not collected and analyzed alumni career and employment related data. Lastly, SSU's institutional leaders expressed interest in the results of this study in order to provide program enhancements for their career and alumni centers.

These research questions were designed to determine which career-services' programming, resources and best practices were most associated with graduates securing full-time employment upon program completion.

My hypothesis is that:

1. SSU alumni who utilized their institutions' career services resources and programming had higher employability outcomes then alumni who did not participate in any of these co-curricular activities.

2. SSU alumni who participated in work-based learning activities (i.e. internships service-learning, and employment opportunities) had higher employability outcomes then graduates who did not participate in any work-based learning activities.

3. SSU women and SSU alumni of color participated in career readiness programming, services and work-based learning opportunities less than their white counterparts. 
4. SSU women and SSU alumni of color who utilized the same career services resources as white male alumni on average took longer to obtain full-time employment.

5. Career-related programming and work-based learning activities that align with the Heuristic Model of Employability lead to higher employment outcomes for SSU alumni.

\section{Definition of Key Terms}

The key terms used in my research question and hypothesis are:

- Emplovability. For this study, employability will be defined as full-time employment after graduation related and/or unrelated to an alumni's area of study.

- Career-readiness programming. For this study will be defined as services provided by universities that promote and support job attainment for students (e.g. career counseling, career center workshops/events, on campus industry networking activities).

- Work-based learning opportunities. For this study, the definition will correspond with the National Research Center for Career and Technical Education definition of work-based learning (i.e. learning technical, academic, and employability skills by working in a real work environment (Alfeld, Charner, Johnson, \& Watts, 2013)). 


\section{Significance of the Study}

Employability for graduating college students remains an issue within the CSU system, and can be attributed to various factors. Originally, various CSUs were contacted for this study, but due to extenuate circumstances, SSU was the only CSU able to participate in this study. One of the main reasons CSUs were unable to participate in the study was due enlarge to alumni tracking. CSU alumni tracking for career services related initiatives and programming has been identified as an ongoing issue by various CSU campuses. Commonly, alumni data is reserved for university and alumni association outreach for graduation tracking, endowment, and fundraising. Unfortunately, career centers having access to alumni personal data to support their centers best practices tends to be overlooked when compared to institutional effectiveness and alumni outreach initiatives. In addition, inadequate funding allocation for career centers continue to create issues around the creation of new programs and the continued enhancement of current career readiness structures. These deficiencies in career center budgets create inequitable access to career-related supports needed to enhance a student's employability outcome; especially when compared to other CSUs and private universities with larger endowments and affluent alumni network.

These inequitable resources especially within the CSU system are evident when comparing graduate placement rates, and career center services and programming 
system-wide. For example, students who are enrolled at Cal Poly San Luis Obispo in Southern California and CSU Maritime Academy in Northern California benefit from these higher employment rates and adequately funded career centers compared to their CSU counterparts. Cal Poly San Luis Obispo advertised their 2018 placement rates at 96\% after 9 months after graduation ("Cal Poly", 2019), and Cal Maritime in that same period had a 92\% placement rate 6 months after graduation (“Cal Maritime”, 2019). Other CSUs including SSU have indicated that they have not previously calculated their placement rates and/or do not have access to the necessary data to report these rates.

An explanation for these high placement rates can be attributed to internally invested resources being allocated to support the employability of their graduates. For example, Cal Poly San Luis Obispo's Career Center offers an array of career related services provided by a s 23 career services personnel, excluding student assistants, servicing 21,000 students. Cal Maritime has 5 career services personnel, excluding student assistants, servicing 1100 students. SSU recently acquired 3 career services personnel providing services for their 9300 students., and San Francisco State University has 7 career services personnel, excluding student assistants, servicing 31,000 students. Access to additional career personnel allow CSUs the ability to increase the number of career-related offerings needed to support the employability of students. To adequately support SSU and CSU students and alleviate these career service inequalities systemwide, each CSU campus must assess what resources are needed to support the 
employability of their current graduates and alumni, determine if their current career services' models are still effective.

\section{Conclusion}

Career centers and their personnel are an invaluable resource for CSU students. They provide instruction and support that supplements a student's learning experience; while enhancing the pathways and access to their careers of choice. Although California State Universities (CSUs) do provide an array of resources and programs that support retention, completion and graduation rates, not all CSUs provide access to adequate resources that enhance the requisite skills students need to transition from higher education into industry. The goal of this case study is to provide evidence that demonstrates the importance of career centers and career-related programming, and to communicate this importance to SSU and other CSU administrators and policymakers. 


\section{Introduction}

\section{CHAPTER TWO: LITERATURE REVIEW}

Career centers have utilized multiple theories to assist students with their career identity, personal adaptability, social capital and human capital. When these components are intact, students demonstrate higher employment outcomes upon program completion. The research in this section introduces and highlights the theories of the Heuristic Model of Employability currently utilized by many career services departments. This model encompasses various career development theories utilized by career counselors, and guides the current programming offered by career centers nationally.

\section{Conceptual Framework}

The Heuristic Model of Employability (Fugate et al, 2004) proposes that employability captures the aspects of three dimensions (i.e. personal adaptability, career identity, and social and human capital), and that interaction facilitates the identification and realization of career opportunities within and between organizations (see Figure 1).

According to this theory, Career Identity (i.e. role identity, occupational identity, and organizational identity) are the ways in which an individual can define themselves in a work context (Fugate et al, 2004). Personal Adaptability refer to the Knowledge, Skills, Abilities, Other characteristics (KSAOs), dispositions, and behaviors, that an individual possesses that allow them to meet the demands of a given situation; especially within a work environment (Ashford \& Taylor, 1990; Chan, 2000). 
Figure 1 Heuristic Model of Employability from Employability: A Psycho-social Construct Its Dimensions and Applications by Fugate, 2004, Journal of Vocational Behavior

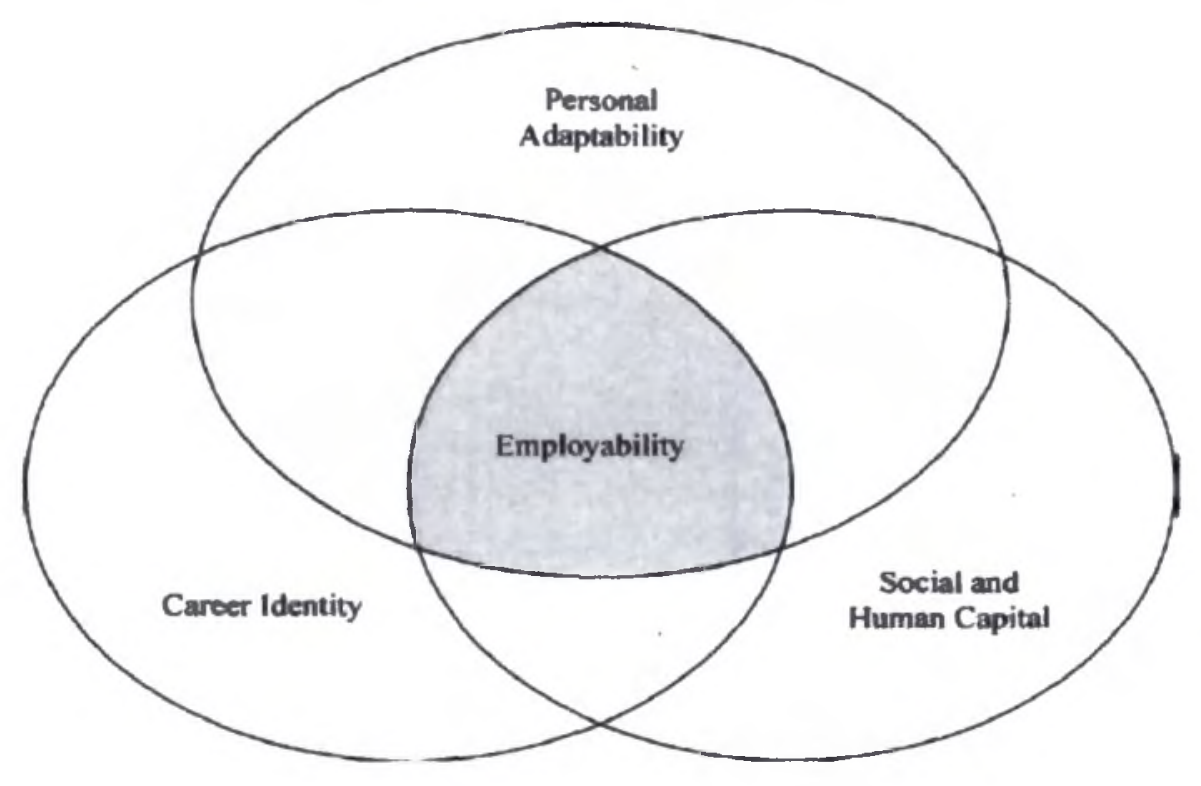

Lastly, Social and Human Capital occurs when individuals and organizations make investments in social and human capital in anticipation of future returns in the workplace (Dess \& Shaw, 2001; Jackson \& Schuler, 1995). When the tenets of this theory are in place, students experience a higher level of employability, and this outcome is the purpose and mission of college career centers. The research highlighted in this section will identify career readiness theories and best practices and demonstrate how when aligned with the tenets of Fugate's Heuristic Model of Employability assist graduates with securing full-time positions within their field of study, successfully support their assimilation into the workforce, and provide the requisite skills employers seek from new hires. 


\section{Employability and the Heuristic Model of Employability}

Employability has many definitions depending on the theory and author. Fugate, Kinicki, and Ashforth (2004), propose that an individual's employability subsumes a host of person-centered constructs (i.e. personal adaptability, career identity, social and human capital) that combine synergistically to help workers effectively adapt to the myriad of work-related changes occurring in today's economy. Hillage, Pollard, and Britain (1998) argue that employability refers to the ability to find early employment, to keep it or to obtain a new employment, which depends on: (a) the range of competencies obtained; (b) the approach to use them and show the acquired competencies to the employers; and (c) the context in which these competencies are employed. Knight and Yorke (2002) highlight the individual characteristics of employability arguing that it is mostly related to several accomplishments in terms of skills and abilities that enable occupational success. Although each author defines employability differently, all authors do identify similar skills and abilities often gained from academic curriculum, career center contact, and work experience need to support employability.

\section{Career Identity and the Heuristic Model of Employability}

Career Centers continue to support the retention, persistence and graduation of students by utilizing multiple theories and programming that assist students with the attainment of their career identity. One of the most common services offered by career centers that support the career identity of students are career exploration courses. Career 
exploration courses are designed to assist students who are undecided about their major. These courses introduce students to majors and career research/decision making strategies that guide their major section ("California Community College Chancellor Office", 2019) In addition to career counseling courses offered by CSUs, career counseling one-on-one sessions are often utilized. During these sessions, counselors discuss similar content presented in career counseling courses.

The theoretical framework that informs both services often revolve around assisting students with the recognition of their self-concepts, and how they change and develop because of time and experiences (Super,1953). Super defines this age range between 15-24 as the "exploration age." During this stage, students often "try out" careers through classes, work experience, and hobbies (Leung, 2008). Career counseling courses and career counselors assist students during this "trying out" phase by recommending courses and majors available at their respective institutions that align with their interests and experiences. This "trying out" phase often includes the use of a career diagnostic surveys that link interests to occupations. These assessments utilize the tenets of Holland's Theory of Occupational Codes.

Holland's Theory of Occupational Codes is currently utilized by U.S. Department of Labor's Employment and Training Administration and is the most widely used model for organizing career interest assessment instruments (Nauta, 2018). Holland believed that people and occupations can be categorized according to six personality types: 
Realistic (R), Investigative (I), Artistic (A), Social (S), Enterprising (E), and Conventional (C), or RIASEC (G. D. Gottfredson \& Holland, 1996). During career counseling appointments and courses, career counselors offer career diagnostic assessments or activities that help students recognize their "occupational codes" and the careers associated with these codes; in order to align a student's interest with their "best fit" career.

Career counselors in addition to occupational codes and interest assessments help students explore other aspects of their lives that contribute and support their career identity. According to Lent, Brown and Hackett (1994), career development and careerrelated choices are best explored as emerging from the complex interactions between individual factors (i.e., self-efficacy, interests, outcome expectancies, and goals), background/personal factors (e.g., ethnicity, predispositions, and gender), and prior learning and achievement-all viewed through the lens of social-cognitive theory (Bandura, 1986). The Social Cognitive Career Theory (SCCT) guides the way career counselors help students reflect on the many aspects of their lives, assist students with interpreting this information, and help students relate this information to occupations/professions that support and align with these personal experiences and their interests.

When career counselors provide these services to students, they enhance the career identity of students thus supporting their employability after graduation. In a study 
to investigate the short-term (i.e., pre-/post-assessment) and long-term (i.e., follow-up intervals of 3 months and 1 year) impacts of a career counseling intervention, 199 French-speaking career counseling clients (101 females and 98 males, ranging from 14 to 56 years old) were provided a brief, individual, face-to-face career counseling intervention. The study found that career decision difficulties significantly decreased between pre- and post-assessment times and continued to moderately decrease at followup times (Perdrix, S., Stauffer, S., Masdonati, J., Massoudi, K \& Rossier, J., 2011). Another study of 61 unemployed job seekers examined the effectiveness of career counseling processes on improved service and current knowledge. Results revealed that the career counseling intervention promoted self-esteem, and three months after the counseling, the intervention clients were considerably more successful in finding employment (or a training course) than those in the comparison group (Littman-Ovadia, H., Lazar-Butbul, V., \& Benjamin.B, 2013). Lastly, in a longitudinal study of 195 career counseling clients, researchers found that when counseling clients participated in career counseling interventions, clients expressed a higher confidence in their ability to realize their career goals at the end of the counseling, encountered less external barriers, made more progress toward their career goals, and had higher goal self-efficacy beliefs six months after the counseling (Verbruggen, M., \& Sels, L., 2010).

In addition to career courses and career counseling sessions, another activity that has been shown to enhance the career identity of students can be found in formal work- 
based learning activities established by higher education institutions in conjunction with community partners/employers (i.e. service learning an internships). These opportunities provide students real world experiences that help students determine if a career aligns with their interest. Esters and Retallick (2013) found that a work-based learning program directly impacted the vocational identity, career decision self-efficacy, and career maturity of undergraduate agriculture and life sciences students. Participants who were enrolled in this program were required to complete an internship with faculty and staff in university research laboratories, farms, greenhouses, administrative units, and other academic entities. Findings indicated that the work-based learning program participation contributed to greater vocational identity, and helped students clarify their career interests and goals.

\section{Social and Human Capital and the Heuristic Model of Employability}

In addition to allocating resources to help students develop their career identity, CSU Career Centers provide services that enhance students' social and human capital within their industry of choice. Social capital is defined as the "features of social organizations, such as networks, norms and trust that facilitate action and cooperation for mutual benefit (Putnam,1993)". Career counseling professionals recognize that the employability of their students is influenced by the amount of social capital a student possesses within their industry of choice. As a result, university activities that increase the social capital of students often revolve around employer engagement activities, such 
as structured networking activities (e.g. career fairs, LinkedIn/social media workshops, and employer networking events). When students participate in these structured networking activities, they cultivate their social capital with industry professionals who in turn provide immediate employment opportunities. These foundational employment opportunities enhance future incomes through the imbedding of resources in people (i.e. human capital (Becker, 1962)), needed for immediate and future advancement.

Some students may enter higher educational institutions with some form of nepotism and/or cronyism that has secured their social and human capital within their career choice already. For those students who may be first generation and/or do not have a network that provides industry related capital, career centers offer activities that create access to resources that support the employability of these student populations.

Research has shown that students who participate in career services' activities (e.g. workshops and events) can leverage these experiences to create access to networks that assist with employability. For example, in a study where surveys were distributed to 93 students who had recently attended a career fair hosted by the Sociology and Criminal Justice Department at Old Dominion University. Students who participated in the Career Fair indicated that the fair provided information about careers, students gained insight about the hiring process with participating agencies, the fair provided information about career options within their area of study, and students were able to establish contacts for their career searches (Payne, B., \& Sumeter, M., 2005). In a study of 84 undergraduate 
and graduate students who were required to create a LinkedIn account and fulfill several key action items, half of the students felt the exercise held promise for their future and represented an opportunity to meet industry experts. For some students, the engagement activities led to actual employment opportunities (Peterson, R., \& Dover, H., 2014).

Work-based learning activities in addition to supporting career identity also provide participants valuable work experience that can assist with future job attainment. For example, Huff and Zoltowski surveyed 523 participants and selected 27 participants who participated in a service-learning program, Engineering Projects in Community Service (EPICS). Qualitative data revealed that EPICS helped participants gain real world opportunities to apply communication, teamwork, and presentation (traits employers are seeking in new hires). Furthermore, participants agreed that EPIC filled a gap between academic and real world, provided them professional experience prior to beginning their careers, and bolstered their confidence and preparations for the workforce. Gomez-Laner (2017), studied students enrolled in an interior design course who participated in a home renovation project as a component of the course. Participants indicated that they gained knowledge in how to resolve real-world problems, helped students build up student portfolios and resumes, and experience in speaking to a client. Coutler (2013) examined the impact of an experiential service-learning project and its effects on participating students compared to sludents who received instruction only. Coulter (2013) concluded 
that students who participated in the service- learning project could recall and explain the concepts more clearly than the students who only participated in instruction.

When students take advantage of career center workshops and work-based learning opportunities, they can articulate their career aspirations to employers more clearly, have related work experience that increases their competitiveness during the application process, and gain access to industries that may be new or foreign to their previous experiences.

\section{Personal Adaptability and the Heuristic Model of Employability}

Career Centers view employability as an interactive and reciprocal process between the individual and the work environment (Dawis \& Lofquist, 1984). The Theory of Work Adjustment (TWA) views career choice and development as continual processes of adjustment and accommodation in which: (a) the person (P) looks for work organizations and environments $(E)$ that would match his/her "requirements" in terms of needs, and (b) $\mathrm{E}$ in turn looks for individuals who have the capabilities to meeting the "requirements" of the organization (Leung, 2008). These knowledge, skills, abilities, and other characteristics demonstrate to employers the dispositions, behaviors, applicants need to meet the demands of a work-related situation (Ashford \& Taylor, 1990; Chan, 2000). This "personal adaptability" can be achieved through internships, campus involvement and similarly related activities generated by career centers and their industry 
partnerships and is articulated to employers during the prescreening and interview process.

Career centers collaborate with industry partners and employers to help students obtain these personal attributes that enhance their employability. Robles (2012), measured student interviews in a junior-level business communication class. 45 business students interviewed two executives each year for their final project. Of these 90 business executives, 49 responded. These executives were asked to list the 10 most important professional attributes they required new employees to possess when hired for any positions within their organization. All $49(100 \%)$ of the executives indicated that integrity and communication were very important or extremely important. Over three fourths of the respondents ( $84.2 \%)$ indicated that courtesy was an extremely important skill, and over half reported that responsibility and interpersonal skills were extremely important. The employers also indicated that they expected students to learn these skills through their formal education

These skill sets are often demonstrated as soft skills. Hard skills are the technical expertise and knowledge needed for a job. Soft skills are character traits, attitudes, and behaviors, personality-specific skills that determine one's strengths as a leader, facilitator, mediator, and negotiator (Robles, 2012). According to an annual study conducted by the National Association of Colleges and Employers (NACE, 2018), these two attributes (i.e. hard and soft skills) are equally important to GPA, with almost 83 
percent of responding organizations saying they seek them, and a large percentage of employers indicating that they search for these attributes on a resume (NACE, 2018). Career centers in addition to helping student obtain these skills, also offer resume, cover letter and interview preparation activities that assist students with highlighting these competencies that demonstrate skill alignment to employers.

\section{Race, Gender, Ethnicity and Employment}

While the research has shown that CSU career centers do provide needed resources for students and alumni that support employment outcomes, there is evidence that other confounding variables influence employment outcomes especially for women and people of color. In a meta-analysis of every available field experiment of hiring discrimination against African Americans or Latinos (55,842 applications submitted for 26,326 positions) since 1989 , whites received on average $36 \%$ more callbacks than African Americans, and 24\% more callbacks than Latinos. This study observed no change in the level of hiring discrimination against African Americans over the past 25 years, although they found modest evidence of a decline in discrimination against Latinos. In addition, when accounting for applicant education, applicant gender, study method, occupational groups, and local labor market conditions does little to alter this result (Quillan, 2017).

Research has also shown that minority men are often excluded from informal job networks and high paying leadership positions (Aliamahomed-Wilson, 2012), and 
women and minorities are often unable to gain access to the economic and social mobility within certain industries because of informal referrals that lead to hirer employability outcomes and educational opportunities for family members and/or acquaintances (Brown, Steren and Topa, 2016). Nepotism and cronyism are examples of these informal referrals, and often used to appoint and/or refer family, friends and/or acquaintance to positions, employment opportunities, career, authority and/ or power (Brown, Steren and Topa, 2016). Lastly, PwC recently released research highlighting that women were more likely to have personally felt gender discrimination during the hiring process, and $28 \%$ of female millennials, expressed the belief that employers were biased in favor of male candidates (PwC, 2018).

These discriminatory recruitment practices prevent access to lucrative careers for women and people of color causing inequitable employment outcomes within industry. Rivera (2012; 2015) interviewed 120 employers in elite law, banking, and management firms, finding that hiring decisions were largely based on independent corporate culture, hiring managers paying particularly close attention to similarities between their own experiences and backgrounds and those of job applicants, "fit" on the basis of their affective, personal connections with applicants, such as positive responses based on similar hobbies or backgrounds. The continuous restriction of access to organizations and industries for certain groups contribute to the hiring process continuing to act as a form of 
cultural gatekeeping and exclusion, where applicants lacking similar characteristics to existing staff (e.g., race, age, gender) could be less likely to obtain a job (Rivera, 2012).

Career development theories and research identify the many benefits associated with career services' related content and curriculum (e.g. higher levels of retention, career identity, workforce readiness and workplace attributes that contribute to higher employability outcomes and preparation). These theories guide the current practices and programming utilized by higher education institutions nationally. However, these theories do not consider studies around race, gender, and their effects on employment outcomes. These factors are important for career centers to analyze and assess as well, only then can career centers ensure that their services are creating equitable outcomes for all students and alumni.

\section{Conclusions and Implications}

Research has shown that there is a disconnect between what academia, industry and students deem as career-ready. Employers believe students are not ready for the workforce after graduation, students believe that higher education institutions are adequately preparing them for the workforce, and higher education institutions believe that they are preparing students for the workforce (Gallup, 2017). Research has also shown that there is a solution to this disconnect. The Heuristic Model of Employability outlines a theory to remedy this disconnect. Services such as career fairs, informational sessions, advising and work-based learning activities have been shown to support the 
employability outcomes of students. These successful outcomes are achieved when career programming, career theories, work-experience and best practices are provided for students. The goal of this case study is to determine if the Heuristic Model of Employability as it relates to career center programming and services enhanced the employability outcomes of SSU alumni. If it did not, then through this case study, SSU will be able to identify best practices utilized by alumni that could potentially be replicated into instructional programming and resources for current students. 


\section{CHAPTER THREE: METHODOLOGY}

This chapter describes the methodology being utilized in this case study. The research design, role of the researcher, setting, instrument, discussion of data collection, and analysis are included in this section.

\section{Research Design and Role of Researcher}

This case study assessed the effectiveness of career readiness programming, services, and work-based learning opportunities on the employment outcomes of Sonoma State University (SSU) alumni. As a career services professional for the past 11 years, I have worked with both employers and students. In my role, I have connected students and alumni to employment opportunities, and employers to new applicants for their organization. A common theme within career services is the need to ensure that centers continue to offer programming and resources that provide students and alumni the requisite skills needed for employment both effectively and efficiently. To ensure that centers are continuing to create these equitable employment outcomes, career centers usually distribute a first destination survey, or any survey that could be utilized to assess graduate career-related outcomes. These surveys help career service professionals determine what industry, employers and best practices were most effective for alumni, and provide data that continue to promote best practices for career centers. While these surveys are important, some CSUs have not tracked their alumni's employment outcomes, and/or collected this data. 


\section{Introduction}

The purpose of this case study was to examine the impacts college career-readiness programming and activities had on the employment outcomes of SSU alumni. Responses were gathered using an adapted instrument from existing first-destination surveys distributed to recent college graduates. First destination surveys are designed to capture information regarding how new college graduates fare in their careers after graduation (NACE, 2019). While first destination surveys are great indicators for graduate placement successes and failures, many first destination surveys do not ask questions that provide insight towards university programming and their effects on the employment outcome of their alumni. As a result, this study was designed to focus on those variables specifically and to determine if employment outcomes were achieved when the careerrelated services were utilized.

The research questions that were designed to assess these outcomes are:

1. How did career services' resources, programming and work-based learning activities support the employability of SSU alumni?

2. How are career services' resources, programing and work-based learning activities providing equitable employment outcomes for all recipients?

3. How are career services' resources, programing and work-based learning activities being utilized by women and students of color compared to their white male counterparts? 


\section{Research Design}

This case study surveyed approximately 8200 Sonoma State University (SSU) alumni who graduated between 2014 and 2018. 613 SSU alumni completed the survey. This study utilized a bivariate analysis (i.e. chi-square test) to detect and describe the relationships between two nominal or ordinal variables (Guerrero, 2012). A bivariate correlational design to measure the relationship between interval-ratio variables, and statistical hypothesis testing (i.e. t-test) to compare two sample means (Guerrero, 2012) were also used for this case study.

Quantitative analysis was ideal due to respondent access limitations. The researcher was provided personal emails of the alumni and granted permission to send a single survey to these alumni. The researcher was not provided any names, phone numbers or addresses of alumni, and informed by SSU to send only the approved survey to alumni. The quantitative analysis evaluated the relationship between the dependent variable (i.e. employment outcomes) and various career preparation independent variables based on the conceptual framework outlined in Chapter 1 .

A level of confidence of $90 \%$ and $10 \%$ level of significance was selected for this case study because the researcher's main goal was to capture statistically significant SSU alumni employment data that could confidently communicate employability best practices and recommendations to SSU and CSU personnel. College career readiness programming is only a piece of the employment puzzle for college students. Students 
must endure additional hardships and barriers that may impede their personal, career and academic success (i.e. food and housing issues, lack of adequate support systems, tuition, academic preparation, etc.). For many students a $10 \%$ level of significance is better than the various societal and educational percentages students must overcome in order to attain their career and life goals (i.e. poverty, student debt, incarceration, attrition rates, etc.). The goal of this case study is to help support students and provide invaluable data that could shift the inequitable circumstances they face. Therefore, the themes that arise from this case study should be captured, reported, and not excluded because there is up to a $10 \%$ chance the results from this data are inaccurate.

\section{Setting and Sample}

This case study was conducted at Sonoma State University located in Sonoma County, CA. To gain access to SSU alumni participants for this case study, the University Advancement and Alumni Association office was contacted. When SSU was originally contacted regarding this study, their campus was in the process of hiring their entire career services center team; as result, the case study was designed based on correspondences between the Office of University Advancement and Alumni Association and the researcher. Follow-up correspondences occurred over a 6-month period and SSU was able to provide the necessary alumni data, indicated that there was a need for this research especially with the lack of career center resources, and received administrative approval for this study to be conducted at their site. 
For this case study a total of 8800 alumni who graduated between 2014 and 2018 were sent the survey via their personal email, and 613 surveys were completed (6.9\% response rate) during the two-week open window. Although the response rate was lower than expected, the overall respondent sample was representative of SSU's student population. Table 1 shows the gender makeup of survey respondents compared to Fall 2018 SSU student enrollment totals.

Table 1. Survey Respondent and SSU Gender Identity

\begin{tabular}{|c|c|c|}
\hline Gender & $\begin{array}{l}\text { Survey } \\
\text { Enrollment } \\
\text { Respondents N (\%) }\end{array}$ & $\begin{array}{c}\text { Fall 2018-SSU } \\
\text { N (\%) } \\
\end{array}$ \\
\hline Males & $114(19 \%)$ & $3508(38 \%)$ \\
\hline Female & $357(58 \%)$ & $5693(62 \%)$ \\
\hline Other & $8(1 \%)$ & . \\
\hline Did not specify & $134(22 \%)$ & \\
\hline
\end{tabular}

Female respondent total compared to Fall 2018 SSU student enrollment total was similar (varying by $2 \%$ ). Male respondent total was underrepresented compared to male Fall 2018 SSU enrollment totals, which may have affected some of the gender analyses used to address research question 2 . This underrepresentation of male respondents will be discussed in the limitation section of this case study.

Racial/ethnic identity of survey respondents and Fall 2018 SSU student enrollment totals were compared and reflected in Table 2. Respondent's ethnicity/race demographic for this case study were fairly similar to SSU Fall 2018 student enrollment 
totals, except for the underrepresentation ( $20 \%$ less) of Hispanic, Latino, or Spanish participants in this research study.

Table 2. Racial/Ethnic Identity of Survey Respondents and SSU Students

\begin{tabular}{lll}
\hline $\begin{array}{l}\text { Participant } \\
\text { Demographics } \\
\text { (Ethnicity/Race) }\end{array}$ & $\begin{array}{l}\text { Survey Respondents } \\
\text { N (\%) }\end{array}$ & $\begin{array}{l}\text { Fall 2018- SSU } \\
\text { Enrollment N (\%) }\end{array}$ \\
\hline $\begin{array}{l}\text { Middle Eastern or North } \\
\text { African }\end{array}$ & $6(0.97 \%)$ & $39(0.4 \%)$ \\
$\begin{array}{l}\text { Asian } \\
\text { Black of African American }\end{array}$ & $30(4.8 \%)$ & $491(5.3 \%)$ \\
$\begin{array}{l}\text { Middle Eastern or North } \\
\text { African }\end{array}$ & $4(0.65 \%)$ & $205(2.2 \%)$ \\
$\begin{array}{l}\text { Native Howaiian or Other } \\
\text { Pacific Islander }\end{array}$ & $6(0.97 \%)$ & \\
$\begin{array}{l}\text { Hispanic, Latino(a), or } \\
\text { Spanish }\end{array}$ & $88(14.3 \%)$ & $28(0.3 \%)$ \\
$\begin{array}{l}\text { White } \\
\begin{array}{l}\text { Multiracial } \\
\text { Unknown }\end{array}\end{array}$ & $312(50.8 \%)$ & $3,205(34.8 \%)$ \\
\hline
\end{tabular}

This underrepresentation will also be addressed in the limitations section of this case study.

\section{Ethics and Protection of Human Subjects}

All participants in this study are alumni who graduated SSU between 2014-2018. To conduct this study, the researcher received Institutional Review Board (IRB) approval from San Francisco State University and Sonoma State University prior to receiving any alumni personal data. All alumni were provided a letter of consent informing them that the survey was voluntary, and at any time could elect to decline participation in this case 
study. In addition, no names or identities were required for participation in this research study, and all correspondences were conducted through the alumni's personal email accounts. Additionally, at the end of this case study, all responses will be deleted by the researcher to ensure confidentiality.

\section{Instrumentation}

The instrument for this survey consisted of 32 questions designed to assess the effectiveness of SSU's career readiness programming, services and work-based learning activities on the employment outcomes of SSU graduates. In addition, the survey was designed to verify whether the tenets of the Heuristic Model of Employability supported the employability of SSU alumni. Data were collected from an original survey consisting primarily of Likert scale (i.e. strongly agree to strongly disagree) questions designed to assess respondents' experiences with their universities' career services programming, participation in work-based learning opportunities and their employment history. All participants received the same survey to complete to ensure reliability of the instrument.

For this case study, the researcher created an instrument similar to Handshakes' First Destination Survey (See Appendix A). Handshakes' First Destination Survey generally seeks responses related to employment attainment and overall campus/institution experience, but do not specifically ask questions related to career center programming/ services and their impacts on employment outcomes. In addition, the researcher incorporated questions from The California Community Colleges' (CCC) 
CTEOS Survey (See Appendix B), which is the CCCs version of a first destination survey for their Career Education graduates.

The combined research instrument asked participants to respond to a 32-Likert scale item assessing their perceptions of the effectiveness of SSU's career-related programming, services, and work-based learning activities had on their employment outcomes after graduation. Participants were asked to respond on a 1 to 5 scale, with 1 indicating Strongly Agree and 5 indicating Strongly Disagree (Appendix C). Participants were also asked to respond to 2 demographic questions regarding gender and race/ethnicity identity. Error! Reference source not found.

\section{Data Collection and Analysis}

The data collected for this study was obtained from 613 out of 8800 SSU alumni (6.9\% response rate) who graduated between 2014-2018. SSU alumni's personal emails were provided by SSU's Office of University Advancement and Alumni Association and received IRB approval from SSU and SFSU Institutional Research Office. The SSU alumni who participated were asked to complete a 32- item online survey. To garner interest in this research study, three $\$ 25$ amazon gift cards were raffled to SSU alumni participants. Upon survey completion, SSU alumni were asked to indicate whether they 
Table 3 highlights the independent and dependent variables from the survey that were used to analyze relationships, correlations and significance for this study. Table 3 also shows the connection of these variables to the components of the Heuristic Model of Employability and identifies each activity and its corresponding model tenet(s).

\section{Data Collection and Analysis}

The data collected for this study was obtained from 613 out of 8800 SSU alumni $(6.9 \%$ response rate) who graduated between 2014-2018. SSU alumni's personal emails were provided by SSU's Office of University Advancement and Alumni Association and received IRB approval from SSU and SFSU Institutional Research Office. The SSU alumni who participated were asked to complete a 32- item online survey. To garner

Table 3. Research Variable Definition Survey question

Variable Type Heuristic Model of Employability component

\begin{tabular}{|c|c|c|}
\hline $\begin{array}{l}\text { About how many months did it } \\
\text { take you to secure full-time } \\
\text { employment after your } \\
\text { graduation? }\end{array}$ & Dependent & Employability \\
\hline $\begin{array}{l}\text { How closely related to your } \\
\text { field of study was your first } \\
\text { full-time job after graduation? }\end{array}$ & Dependent & Employability \\
\hline $\begin{array}{l}\text { One-on-one meetings with } \\
\text { Sonoma State faculty advisors } \\
\text { and/or career center personnel } \\
\text { were helpful to me. }\end{array}$ & Independent & $\begin{array}{l}\text { Career Identity and Personal } \\
\text { Adaptability }\end{array}$ \\
\hline Participation in Career Fairs & Independent & $\begin{array}{l}\text { Career Identity, Social and } \\
\text { Human Capital }\end{array}$ \\
\hline
\end{tabular}




\begin{tabular}{|c|c|c|}
\hline $\begin{array}{l}\text { Participation in Informational } \\
\text { Sessions }\end{array}$ & Independent & $\begin{array}{l}\text { Career Identity, Social and } \\
\text { Human Capital, Personal } \\
\text { Adaptability }\end{array}$ \\
\hline Participation in Internships & Independent & $\begin{array}{l}\text { Career Identity, Social and } \\
\text { Human Capital, Personal } \\
\text { Adaptability }\end{array}$ \\
\hline $\begin{array}{l}\text { Participation in Service } \\
\text { Learning }\end{array}$ & Independent & $\begin{array}{l}\text { Career Identity, Social and } \\
\text { Human Capital, Personal } \\
\text { Adaptability }\end{array}$ \\
\hline $\begin{array}{l}\text { Participation in Employment } \\
\text { Opportunities While Enrolled in } \\
\text { School }\end{array}$ & Independent & $\begin{array}{l}\text { Career Identity, Social and } \\
\text { Human Capital, Personal } \\
\text { Adaptability }\end{array}$ \\
\hline $\begin{array}{l}\text { Hard and Soft Skills from } \\
\text { Internships }\end{array}$ & Independent & $\begin{array}{l}\text { Career Identity and Personal } \\
\text { Adaptability }\end{array}$ \\
\hline $\begin{array}{l}\text { Hard and Soft Skills from } \\
\text { Service-Learning }\end{array}$ & Independent & $\begin{array}{l}\text { Career Identity and Personal } \\
\text { Adaptability }\end{array}$ \\
\hline $\begin{array}{l}\text { Hard and Soft Skills from } \\
\text { Employment Opportunity while } \\
\text { Enrolled in School }\end{array}$ & Independent & $\begin{array}{l}\text { Career Identity and Personal } \\
\text { Adaptability }\end{array}$ \\
\hline
\end{tabular}

interest in this research study, three $\$ 25$ amazon gift cards were raffled to SSU alumni participants. Upon survey completion, SSU alumni were asked to indicate whether they would like to participate in the raffle by reentering their personal emails in the last question of the survey. The online survey was distributed and processed using Qualtrics, once data was received, descriptive and interpretive analysis were conducted using SPSS software, and gift cards were awarded to the winners after the survey closing date.

Validity and Reliability

Previously established instruments (i.e. CTEOS Survey and Handshake Survey) were utilized in this study to assess the effectiveness of career-related programming, 
services and work-based learning activities had on the employment outcomes of SSU alumni. These instruments were selected because of the frequency of their usage within the CSU, community college and UC system. Multiple campuses and institutions have used these surveys to accurately track the employment outcomes of their alumni, and as a result, the content of these surveys was adopted for this research study. In addition, all alumni completed the same 32-item online survey to ensure that the results and methodology were reliable and sound.

\section{Summary}

The purpose of the quantitative case study was to assess the effectiveness of career-related programming, services and work-based learning activities on the employment outcomes of SSU alumni. 613 out of $8800 \mathrm{SSU}$ (6.9\% response rate) alumni participated in this study by completing a 32 - item online survey that was distributed via Qualtrics software and analyzed using SPSS software program. Consent was sent and confirmed by all respondents, and the study received IRB approval from SFSU and SSU. 


\section{CHAPTER FOUR: REPORT OF FINDINGS}

This chapter discusses the impact career-related services, programming and workbased learning opportunities had on the employment outcomes of Sonoma State University (SSU) alumni. The data collected for this study was obtained using a newly constructed first-destination survey that adapted previously validated survey instruments from the National Association of College and Employers (NACE,2019) and California Community College Chancellor's office CTEOS survey (CTEOS, 2019). For this study, approximately 8,800 Sonoma State alumni who graduated between 2014- 2018 were invited to participate. A total of $613 \mathrm{SSU}$ alumni completed the 32-question survey, constituting a lower bound response rate of $6.9 \%$. The data collected were used to ascertain:

1. How did career services' resources, programming and work-based learning activities support the employability of SSU alumni?

2. How are career services' resources, programing and work-based learning activities providing equitable employment outcomes for all recipients?

3. How are career services' resources, programing and work-based learning activities being utilized by women and students of color compared to their white male counterparts? 


\section{Data Analysis}

All responses were recorded using Qualtrics software then exported to SPSS for analysis. Independent, dependent and demographic variables were recoded in SPSS prior to analysis. Table 4 illustrates the recoding and operationalization of these variables for some of the specific analyses.

Table 4. Conceptual Variables and Demographics and their Operationalization

\begin{tabular}{|c|c|}
\hline Variable & Operationalization \\
\hline Employed & Recoded $0-1$ \\
\hline after & Employment was recoded as follows: \\
\hline graduation & $\begin{array}{l}\text { Found work during enrollment and continued to work after } \\
\text { graduation }=1 ; \text { Found work months after graduation }=1 \text {; } \\
\text { Still seeking working }=0\end{array}$ \\
\hline Career Fair & Recoded $0-1$ \\
\hline Participation & $\begin{array}{l}\text { Career Fair was recoded as follows: Strongly agree, agree, neutral, } \\
\text { disagree, strongly disagree }=1 \text {; Did not participate in career fair }=0\end{array}$ \\
\hline SSU & Recoded $0-1$ \\
\hline $\begin{array}{l}\text { Advising } \\
\text { participation }\end{array}$ & $\begin{array}{l}\text { SSU Advising was recoded as follows: Strongly agree, agree, neutral, } \\
\text { disagree, strongly disagree }=1 \text {; Did not participate in SSU advising }=0\end{array}$ \\
\hline Informational & Recoded 0-1 \\
\hline $\begin{array}{l}\text { Sessions } \\
\text { participation }\end{array}$ & $\begin{array}{l}\text { Informational sessions were recoded as follows: Strongly agree, } \\
\text { agree, neutral, disagree, strongly disagree }=1 \text {; Did not participate in } \\
\text { info sessions }=0\end{array}$ \\
\hline Career- & Recoded 0-1 \\
\hline $\begin{array}{l}\text { readiness } \\
\text { workshops } \\
\text { participation }\end{array}$ & $\begin{array}{l}\text { Career readiness workshops were recoded as follows: Strongly agree, } \\
\text { agree, neutral, disagree, strongly disagree }=1 \text {; Did not participate in } \\
\text { career fair }=0\end{array}$ \\
\hline Internship & Recoded 0-1 \\
\hline Participation & $\begin{array}{l}\text { Internship participation was recoded as follows: } \\
\text { Yes }=1 ; N_{0}=0\end{array}$ \\
\hline Service- & Recoded $0-1$ \\
\hline Learning & Service-learning participation was recoded as follows: \\
\hline Participation & Yes $=1 ; N_{0}=0$ \\
\hline
\end{tabular}




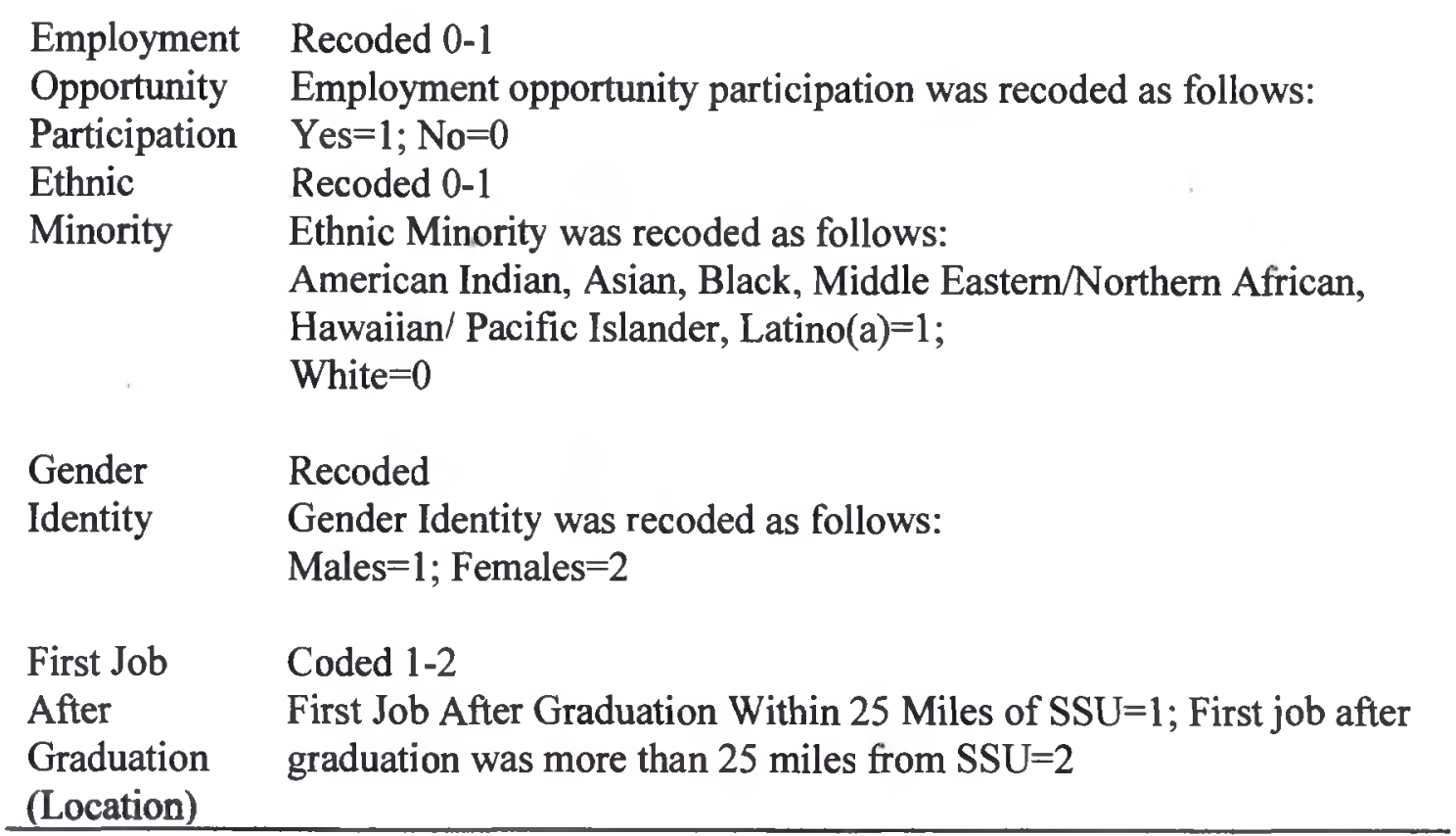

\section{The Findings}

Three research questions guided this study and provided insight to determine if there were relationships and/or correlations between career-readiness programming, services, and work-based learning activities. For each of the research questions, a level of confidence of $90 \%$ and level of significance of $10 \%$ was selected.

Research question 1. This question was designed to explore the degree to which career services' resources, programming, and work-based learning activities utilized by SSU alumni supported their employment after graduation. For this question, two employability groupings were created and compared to the various career services' programs and work-based learning activities. Respondents who indicated that they successfully secured a full-time position any time after graduation, and the respondents 
who did not successfully find full-time employment after graduation were clustered into an employment grouping (Table 5), and coded as either 1(employed) or 0 (not employed).

Table 5. Employment Grouping for SSU Alumni

\begin{tabular}{|c|c|c|}
\hline & Survey Respondents n (\%) & $\begin{array}{l}\text { Analysis } \\
\text { Coding }\end{array}$ \\
\hline Not employed any time after graduation & $103(16.8 \%)$ & 0 \\
\hline Employed after graduation & $427(69.7 \%)$ & 1 \\
\hline Did not respond & $83(13.5 \%)$ & \\
\hline Total & $613(100 \%)$ & \\
\hline
\end{tabular}

The second employment grouping that was created, originated from question \#1 of the survey, which asked respondents to report (in months) how long it took them to secure a full-time position after graduation. Both employment groupings were compared to advising, career fair, career-readiness workshop, informational session and work-based learning activity participants separately to determine if participation in these types of programming alone yielded higher employment outcomes for participants.

The results from multiple chi-square analyses comparing whether career-related programming and work-based learning activities alone had any impact on job attainment showed no significance for all analyses (see Table 6).

Table 6. Chi-Square Analyses of Career-Related Programming Participants, WorkBased Learning Activity Participants and the Employment Grouping

\begin{tabular}{ll}
\hline Career-Related Programming and Activities & \multicolumn{1}{c}{$\mathbf{p ~ v a l u e ~}\left(\boldsymbol{\chi}^{2}\right)$} \\
\hline Career Fair Participants & $\chi^{2}=.631, \mathrm{df}=1, \mathrm{p}=.427$ \\
Career Readiness Workshops & $\chi^{2}=1.293, \mathrm{df}=1, \mathrm{p}=.255$ \\
Informational Sessions & $\chi^{2}=.358, \mathrm{df}=1, \mathrm{p}=.550$
\end{tabular}


Advising Participants

Internships Participants

Service-Learning Participants

Employed While Enrolled at SSU $\chi^{2}=.531, \mathrm{df}=1, \mathrm{p}=.466$

$\chi^{2}=.410, \mathrm{df}=1, \mathrm{p}=.522$

$\chi^{2}=.056, \mathrm{df}=1, \mathrm{p}=.813$

$\chi^{2}=.156, \mathrm{df}=1, \mathrm{p}=.692$

T-test analyses comparing the months it took SSU alumni to secure employment after graduation was compared to all career-related programming and work-based learning respondents who indicated that they participated in one of these activities while enrolled at SSU. The results of these analyses revealed two occurrences of statistical significance between internship participants (see Table 7), and career-readiness participants (see Table 7).

Table 7. Months it Took Internship Participants to Secure Full-Time Employment After Graduation

\begin{tabular}{lllll}
\hline & $\begin{array}{l}\text { Internship } \\
\text { Participants }\end{array}$ & N & Mean & $\begin{array}{l}\text { Std. } \\
\text { Deviation }\end{array}$ \\
\hline $\begin{array}{l}\text { Months it Took to Secure Full- } \\
\begin{array}{l}\text { Time Employment After } \\
\text { Graduation }\end{array}\end{array}$ & No & 124 & 8.84 & 11.098 \\
& Yes & 123 & 6.74 & 7.219 \\
\hline
\end{tabular}

Note: $(\mathrm{t}=1.760, \mathrm{df}=245, \mathrm{p}<.10,(\mathrm{p}=.079))$

Results from this analysis showed that SSU alumni who participated in internships on average took 2 months less to secure a full-time position after graduation compared to SSU alumni who did not participate in internships.

A t-test analysis comparing career-readiness workshop participants and months it took respondents to secure a full-time position revealed a statistically significant relationship was present (see Table 8). Data showed that career-readiness participants on 
average took 1 month less to secure a full-time position after graduation compared to alumni who did not utilize this service.

Table 8. Months it Took Career-Readiness Workshop Participants to Secure Full-Time Employment After Graduation

\begin{tabular}{llll}
$\begin{array}{l}\text { Career- } \\
\text { Readiness } \\
\text { Participants }\end{array}$ & Mean & $\begin{array}{l}\text { Std. } \\
\text { Deviation }\end{array}$ \\
\hline
\end{tabular}

\begin{tabular}{lcccc}
\hline $\begin{array}{l}\text { Months it Took to Secure } \\
\text { Full-Time Employment } \\
\text { After Graduation }\end{array}$ & No & 163 & 8.50 & 10.499 \\
& Yes & 85 & 6.65 & 6.923 \\
\hline
\end{tabular}

Note: $(\mathrm{t}=1.661, \mathrm{df}=232.739, \mathrm{p}<.10,(\mathrm{p}=.098))$

All other analyses comparing months it took to secure a full-time position after graduation to other career-readiness programming and work-based learning activities were conducted and showed no statistical significance (see Table 9).

Table 9. Months it Took Career-Related Programming and Work-Based Learning Activities to Secure Full-Time Employment After Graduation

\begin{tabular}{lc} 
Career-Related Programming and Activities & \multicolumn{1}{c}{$\mathbf{p}$ value $(t)$} \\
\hline Career Fair Participants & $\mathrm{t}=.862, \mathrm{df}=210.246, \mathrm{p}=.390$ \\
Informational Sessions & $\mathrm{t}=1.602, \mathrm{df}=187.942, \mathrm{p}=.111$ \\
Advising Participants & $\mathrm{t}=-.935, \mathrm{df}=167.275, \mathrm{p}=.351$ \\
Service-Learning Participants & $\mathrm{t}=1.323, \mathrm{df}=130.961, \mathrm{p}=.188$ \\
Employed While Enrolled at SSU & $\mathrm{t}=-1.144, \mathrm{df}=232.381, \mathrm{p}=.254$ \\
\hline
\end{tabular}

In addition to the independent variables being analyzed separately, various combinations of services, resources and work-based learning variables were combined and compared to the employment grouping. The goal of these analyses was designed to determine if any variations of career-related programming and work-based learning 
activities yielded higher respondent employment outcomes. The first set of chi-square analyses combined one work-based learning activity with one career-related activity, and these groupings were compared to the employed after graduation grouping. The results from these analyses showed no statistical significance for all combined variables when to compared to the employed after graduation grouping (see Table 10).

Table 10. Chi-Square Analyses of Career-Related Programming Participants, WorkBased Learning Activity Participants and the Employment Grouping Career-Related Programming and Work-Based p value $\left(\chi^{2}\right)$ Learning Activities Groupings

Internship and Advising Participants

$$
\chi^{2}=.524, \mathrm{df}=2, \mathrm{p}=.770
$$

Internship and Career Fair Participants

$$
\chi^{2}=.019, \mathrm{df}=1, \mathrm{p}=.890
$$

Internship and Informational Session Participants

$\chi^{2}=1.171, \mathrm{df}=1, \mathrm{p}=.279$

Internship and Career-Readiness Workshop

$\chi^{2}=1.803, \mathrm{df}=2, \mathrm{p}=.406$

Participants

Employment During SSU Enrollment and Advising

$\chi^{2}=1.512, \mathrm{df}=2, \mathrm{p}=.470$

Participants

Employment During SSU Enrollment and

Informational Session Participants

Employment During SSU Enrollment and Career Fair

Participants

Employment During SSU Enrollment and Career-

Readiness Workshop Participants

Service-Learning and Advising Participants

$\chi^{2}=.620, \mathrm{df}=1, \mathrm{p}=.431$

$\chi^{2}=.036, \mathrm{df}=1, \mathrm{p}=.850$

$\chi^{2}=.008, \mathrm{df}=1, \mathrm{p}=.929$

$\chi^{2}=3.292, \mathrm{df}=2, \mathrm{p}=.193$

Service-Learning and Career Fair Participants

$\chi^{2}=.096, \mathrm{df}=1, \mathrm{p}=.757$

Service-Learning and Career- Readiness Workshop

$\chi^{2}=.029, \mathrm{df}=1, \mathrm{p}=.866$

Participants

Service-Learning and Informational Session

$\chi^{2}=1.830, \mathrm{df}=1, \mathrm{p}=.176$

Participants 
The next set of chi-square analyses compared all combined career-related workshops without work-based learning activities to this same employment grouping and found no statistical significance (see Table 11).

Table 11. Chi-Square Analyses of Career-Related Programming Participants, WorkBased Learning Activity Participants and the Employment Grouping

\begin{tabular}{l|c}
\hline Career-Related Programming Groupings & $\mathrm{p}$ value $\left(\chi^{2}\right)$ \\
\hline Career Fair and Career-Readiness Workshop & $\chi^{2}=1.409, \mathrm{df}=1, \mathrm{p}=.235$ \\
Participants & \\
Career Fair and Informational Session Participants & $\chi^{2}=.501, \mathrm{df}=1, \mathrm{p}=.479$ \\
Career Fair and Advising Participants & $\chi^{2}=.258, \mathrm{df}=1, \mathrm{p}=.611$ \\
Career-Readiness Workshop and Informational Session & $\chi^{2}=.148, \mathrm{df}=1, \mathrm{p}=.700$ \\
Participants & $\chi^{2}=.351, \mathrm{df}=1, \mathrm{p}=.554$ \\
Career-Readiness Workshops and Advising & \\
Participants & $\chi^{2}=1.853, \mathrm{df}=1, \mathrm{p}=.173$ \\
\hline
\end{tabular}

The results from these chi-square analyses show that none of the work-based learning activities and career-related programming combinations yielded any statistically significant results when compared to respondents who indicated that they were able or unable to obtain a full-time position after graduation.

The next set of t-test analyses were conducted to determine if any combination of work-based learning activities and career-related services and programs impacted the length of time it took alumni to secure positions after graduation. When work-based learning activities were paired with other career-related programs and compared to months it took SSU alumni to secure positions, only the internship groupings had statistically significant results. A t-test analysis revealed that participation in internships 
and career-readiness workshops compared to the length of time it took respondents to secure a position after graduation was the most statistically significant occurrences of this case study $(\mathrm{p}=.001)$, see Table 12 .

Table 12. Months it Took Internships and Career-Readiness Workshop Participants to Secure Full-Time Employment After Graduation

$\begin{array}{llll}\text { Internships and Career- } & \text { N } & \text { Mean } & \begin{array}{l}\text { Std. } \\ \text { Deviation }\end{array}\end{array}$

\begin{tabular}{lclll}
\hline $\begin{array}{l}\text { Months it took to } \\
\text { secure full-time } \\
\text { employment }\end{array}$ & Yes & 41 & 5.22 & 3.978 \\
\hline
\end{tabular}

Note: $(\mathrm{t}=3.292, \mathrm{df}=157.349, \mathrm{p}<.10,(\mathrm{p}=.001))$

The results from this analysis revealed that on average, respondents who participated in both internships and career-readiness workshops were able to secure full-time positions 2.5 months faster than respondents who did not participate in both internships and careerreadiness programming.

Similarly, another t-test analysis revealed that on average, respondents who participated in both internships and informational sessions secured full-time positions approximately 2.5 months faster than respondent who did not participate in this combination of work-based learning and career-related programming (see Table 13).

Table 13. Number of Months it Took Internship and Informational Sessions Participants to Secure Full-Time Emploment After Graduation

\begin{tabular}{llll}
$\begin{array}{l}\text { Internship and } \\
\text { Informational Session } \\
\text { Participation }\end{array}$ & $\mathbf{N}$ & Mean & $\begin{array}{l}\text { Std. } \\
\text { Deviation }\end{array}$ \\
\hline Yes & 41 & 5.41 & 7.190
\end{tabular}


$\begin{array}{lllll}\text { Months it took to } & \text { No } & 206 & 8.27 & 9.736\end{array}$ secure full-time employment

Note: $(\mathrm{t}=2.174, \mathrm{df}=72.634, \mathrm{p}<.10,(\mathrm{p}=.033))$

Additionally, a t-test analysis revealed that internships and advising participation had some statistical significance when compared to length of time to secure full-time employment after graduation $(\mathrm{p}=.062)$. On average, respondents who utilized both services indicated that they secured full-time positions 2 months faster than respondents who did not utilize this combination of services (See Table 14).

Table 14. Number of Months it Took Internship and Advising Participants to Secure FullTime Emploment After Graduation

\begin{tabular}{lllll}
\hline & Internship and Advising & N & Mean & Std. Deviation \\
\hline $\begin{array}{l}\text { Months it took to } \\
\text { secure full-time }\end{array}$ & Yes & 97 & 6.52 & 7.080 \\
employment & No & 150 & 8.62 & 10.589 \\
\hline
\end{tabular}

Note: $(\mathrm{t}=1.872, \mathrm{df}=244.706, \mathrm{p}<.10,(\mathrm{p}=.062))$

Lastly, internships and career fair participation yielded statistically significant results when compared to number of months needed to secure employment after graduation $(\mathrm{p}=.053)$. Respondents indicated that on average, internship and career fair participants were able to secure full-time positions approximately 2.5 months faster than participants who did utilize these combinations of services (see Table 15).

Table 15. Number of Months it Took Internship and Career Fair Participants to Secure Full-Time Emploment After Graduation

\begin{tabular}{lcll}
$\begin{array}{l}\text { Internship and } \\
\text { Career Fair }\end{array}$ & N & Mean & $\begin{array}{l}\text { Std. } \\
\text { Deviation }\end{array}$ \\
\hline Yes & 39 & 5.54 & 7.355
\end{tabular}


$\begin{array}{lllll}\text { Months it took to secure } & \text { No } & 208 & 8.22 & 9.703\end{array}$ full-time employment Note: $(\mathrm{t}=1.974, \mathrm{df}=65.563, \mathrm{p}<.10,(\mathrm{p}=.053))$

When combining other work-based learning activities with career-related programming and comparing these groupings to months alumni needed to secure fulltime employment, there consistently wasn't any statistical significance in any of the analyses (see Table 16).

Table 16. T-Test Analyses of Career-Related Programming Participants, Work-Based Learning Activity Participants and Months it Took SSU Alumni to Secure Full-Time

\begin{tabular}{|c|c|}
\hline $\begin{array}{l}\text { Work-Based Learning and Career-Related } \\
\text { Programing Groupings }\end{array}$ & p value $(t)$ \\
\hline Service-Learning and Career-Readiness Participation & $\mathrm{t}=1.027, \mathrm{df}=36.908, \mathrm{p}=.311$ \\
\hline Employment During Enrollment and Career-Readiness & $\mathrm{t}=1.160, \mathrm{df}=138.534$, \\
\hline $\begin{array}{l}\text { Service-Learning and Informational Sessions } \\
\text { Participation }\end{array}$ & $\mathrm{t}=.518, \mathrm{df}=34.274, \mathrm{p}=.608$ \\
\hline $\begin{array}{l}\text { Employment During Enrollment and Informational } \\
\text { Sessions Participation }\end{array}$ & $t=.896, d f=94.666, p=.373$ \\
\hline Service-Learning and Advising Participation & $\begin{array}{l}t=.868, d f=113.432, \\
p=.387\end{array}$ \\
\hline $\begin{array}{l}\text { Employment During Enrollment and Advising } \\
\text { Participation }\end{array}$ & $\begin{array}{l}t=-1,642, d f=186.977 \\
p=.102\end{array}$ \\
\hline
\end{tabular}

Research question 2. This question was designed to explore the degree in which career services' resources, programming, and work-based learning activities provided equitable employment outcomes for all recipients. For this question respondents who indicated that they were not white $(\mathrm{N}=194)$ were compared to white respondents. $(\mathrm{N}=338)$. In addition, male respondents $(\mathrm{N}=114)$ were compared to female respondents $(\mathrm{N}=357)$ across all employment groupings (i.e. secured full-time positions and length of time). When all 
variables and groupings were compared, one statically significant outcome arose from the analysis between gender and employment (Table 17)

Table 17. Gender and Employment Outcomes

\begin{tabular}{llll}
\hline & Male & Female \\
\hline Employment & Employed after graduation & 16 & 75 \\
& $\begin{array}{l}\text { Not employed after graduation } \\
\text { (anytime) }\end{array}$ & 98 & 280 \\
Total & & 114 & 355 \\
\hline
\end{tabular}

Note: $\left(\chi^{2}=2.775, \mathrm{df}=1, \mathrm{p}<10(\mathrm{p}=.096)\right)$

This chi-square analysis revealed that male respondents reported higher employment outcomes compared to female respondents. In all other analyses, gender and ethnicity had no statistical significance when compared to the employment grouping and months it took respondents to secure full-time positions groupings.

Research question 3. This question was designed to explore the degree in which career services' resources, programing and work-based learning activities were being utilized by women and students of color compared to white male counterparts. For this question, respondents who indicated that they were not white $(\mathrm{N}=194)$ were compared to white respondents $(\mathrm{N}=338)$. In addition, male respondents $(\mathrm{N}=114)$ were compared to female respondents $(\mathrm{N}=357)$ across all career services resource programs, services and workbased-learning activities. When compared, there were multiple instances of statistical significance between the groupings.

The first instance of significance occurred when the male and female groupings were compared to career- readiness workshop participants. Table 18 shows the number of 
male and female respondents who did/did not participate in career-readiness workshops. Approximately double the number of female respondents participated in career-readiness workshops compared to their male counterparts. Although a higher number of female respondents did participate in career-readiness workshops (i.e. 110 female respondents and 50 male respondents), a higher percentage of male survey respondents participated in career-readiness workshops compared to female respondents (i.e. $43 \%$ male respondents compared to $30 \%$ female respondents).

Table 18. Gender and Career-Readiness Participation

\begin{tabular}{llll}
\hline & & Male & Female \\
\hline Career-readiness & Did not Participate & 64 & 247 \\
participants & Participated & 50 & 110 \\
Total & & 114 & 357 \\
\hline
\end{tabular}

Note: $\left(\chi^{2}=6.558, \mathrm{df}=1, \mathrm{p}<.10(\mathrm{p}=.010)\right)$

The next instance of significance occurred when the male and female groupings were compared to advising participants. Table 19 shows the number of male and female respondents who did/did not participate in SSU advising services. Table 19 also shows that more than double the number of female respondents utilized SSU advising services, but the percentage of male respondents who utilized advising was slightly higher than female respondents (i.e. $82 \%$ males respondents compared to $71 \%$ female respondents). 
Table 19. Gender and Advising Participation

\begin{tabular}{llll}
\hline & & Male & Female \\
\hline Advising & Did not Participate & 20 & 102 \\
& Participated & 94 & 255 \\
Total & & 114 & 357 \\
\hline
\end{tabular}

Note: $\left(\chi^{2}=5.475, \mathrm{df}=1, \mathrm{p}<.10(\mathrm{p}=.019)\right)$

The next instance of significance occurred when the male and female groupings were compared to informational session participants. Table 20 shows the number of male and female respondents who did/did not participate in SSU career informational sessions. Table 20 shows that almost three-times the number of female respondents utilized SSU informational sessions, but the percentage of male respondents who utilized informational session was slightly higher than female respondents (i.e. $43 \%$ males respondents compared to $29 \%$ female respondents).

Table 20. Gender and Informational Sessions Participants

\begin{tabular}{llll}
\hline & & Male & Female \\
\hline Info Sessions & Did not Participate & 64 & 252 \\
& Participated & 50 & 105 \\
Total & & 114 & 357 \\
\hline
\end{tabular}

Note: $\left(\chi^{2}=8.169, \mathrm{df}=1, \mathrm{p}<.10(\mathrm{p}=.004)\right)$

The results of the analysis of the two groups revealed that there was some significance between informational sessions participation and gender at the $\mathrm{p}=.004$.

The next instance of significance occurred when the male and female groupings were compared to internship participants. The results of the analysis of the two groups revealed that there was some significance between internship participation and gender 
$(\mathrm{p}=.003)$. Table 21 shows the number of male and female respondents who did/did not participate in internships. Table shows that more than four times the number of female respondents participated in internships compared to male respondents, and a considerably higher percentage of female respondents utilized internships compared to male respondents (i.e. $58 \%$ female respondents compared to $42 \%$ male respondents).

Table 21. Gender and Internship Participants

\begin{tabular}{llll}
\hline & & Male & Female \\
\hline Internships & Yes & 49 & 210 \\
& No & 65 & 147 \\
Total & & 114 & 357 \\
\hline
\end{tabular}

Note: $\left(\chi^{2}=8.760, \mathrm{df}=1, \mathrm{p}<.10(\mathrm{p}=.003)\right)$

The next instance of significance occurred when the male and female groupings were compared to service-learning participants. Table 22 shows the number of male and female respondents who did/did not participate in service-learning opportunities. Table 22 shows that double the percentage (i.e. $32 \%$ females respondent compared to $14 \%$ male respondents) of female respondents participated in service-learning compared to male respondents. In addition, more than six times the number of female respondents participated in service-learning activities compared to male respondents (116 female respondents compared to 17 male respondents). 
Table 22. Gender and Service-Learning Participants

\begin{tabular}{lllll}
\hline & & Male & Female & Other \\
\hline Service-learning Participants & Yes & 17 & 116 & 1 \\
& No & 97 & 238 & 7 \\
Total & & 114 & 354 & $\mathbf{8}$ \\
\hline
\end{tabular}

Note: $\left(\chi^{2}=13.515, \mathrm{df}=1, \mathrm{p}<.10(\mathrm{p}=0.00)\right.$

\section{Summary and Synthesis}

In summary, the analysis of the data collected identified some statistically significant results related to gender, employment, career-related programming, services and work-based learning activities. The most consistent statistically significant outcomes occurred when internships were included in the analyses. In almost all analyses that included internships combined with any career-related programming variable impacted SSU respondent's employment outcomes. In addition, data showed that alumni who participated in internships combined with career-related programming on average required less time (i.e. approximately 2 months less time) to secure full-time positions after graduation.

When gender and ethnicity were analyzed, the data showed that male respondents secured full-time positions at higher rates than female respondents. The data also showed that ethnicity did not have any statistical significance when compared to the employment outcomes of white SSU alumni respondents. Lastly, the data indicated that male participants utilized career-readiness workshops, informational sessions and advising more than female respondents, but female respondents utilized work-based learning 
activities at higher rates than male respondents. The data from this section provide valuable insight for enhancing employability outcomes for various student populations by reinforcing the notion that career-related programming and work-based learning activities support and impact the employability of alumni. 


\section{CHAPTER FIVE: DISCUSSION AND RECOMMENDATIONS}

\section{Overview}

The purpose of this case study is to assess whether career-related programming, services and work-based learning activities had any effects on the employment outcomes of SSU alumni. Three research questions were created to determine whether these services supported employment outcomes for alumni.

1. How did career services' resources, programming and work-based learning activities support the employability of SSU alumni?

2. How are career services' resources, programing and work-based learning activities providing equitable employment outcomes for all recipients?

3. How are career services' resources, programing and work-based learning activities being utilized by women and students of color compared to their white male counterparts?

\section{Interpretation of Findings}

Quantitative data relating to question 1 revealed that any combination of workbased learning and career-related programming had no significant effects on whether respondents indicated if they were employed or unemployed any time after graduation. Work-based learning and career-related programming did however have statistical significance when compared to length of time respondents required to secure full-time positions after graduation. Respondents who utilized only internships and only career- 
readiness workshops required less time to secure a full-time position after graduation compared to respondents who did not utilize any of these services ( $p=.079$ and $p=.098$ ). On average, respondents indicated that they required approximately 2 months less time compared to respondents who did not utilize any of these services.

Data also showed when internships were combined with various career-related programming, respondents required even less time to secure full-time positions after graduation (see Table 23).

Table 23. Internship and Career-Related Programming, and Months Required to Secure Full-Time Positions After Graduation

\begin{tabular}{lcc}
\hline $\begin{array}{l}\text { Career-Related Programming and Work- } \\
\text { Based Learning Activities Groupings }\end{array}$ & Months & $\begin{array}{c}\text { p value } \\
(\boldsymbol{t})\end{array}$ \\
\hline Internship and Career-Readiness Workshops & 3 Months Less & .001 \\
Internship and Informational Sessions & 2.8 Months Less & .033 \\
Internship and Career Fair Participants & $\begin{array}{c}2.5 \text { Months } \\
\text { Less }\end{array}$ & .053 \\
Internship and Advising Participants & $\begin{array}{c}\text { 2 months } \\
\text { Less }\end{array}$ & .062 \\
\hline
\end{tabular}

In addition, internships compared to other work-based learning activities impacted employment outcomes at higher rates. This is of note because internships compared to other work-based learning activities are purposely designed to provide exposure to a specific major and/or job a student is seeking to pursue after graduation. Internships help students gain access to an industry/organization and provide students the KSAOs needed to successfully transition into various industries and occupations upon graduation. Internships not only provide students the requisite skills needed to access an industry and 
organization, but also allow companies the opportunity to vet future applicants by monitoring and assessing the KSAOs interns demonstrate during their internship. Interns who successfully demonstrate an organization's KSAOs can leverage those skills and relationships to create access within that organization or similar organizations that provide comparable services. Internships allow students the opportunity to access to all the tenets of the Heuristic Model of Employability compared to other work-based learning opportunities. As a result, internships alone and combined with other careerrelated services are statistically significant to employment outcomes.

These findings are important because they align and support the tents of the theory of the Heuristics Model of Employability outlined in Chapter 2. Internships and career services' programming support the employability of SSU and CSU students. When students participate in activities that support the tenets of the Heuristic Model of Employability, employability outcomes increase. Data from this case study also highlight the importance of the synergistic support students need for their employability. For example, when career-readiness activities and internships are utilized separately, they provide some statistically significant employment outcomes for students, but the impact and level of significance is higher when all tenets are present and utilized by students. Students who utilize internships combined with various career-related services can demonstrate the requisite hard and soft skills employers seek in applicants. In addition, they have access to the KSAOs, and social and human capital needed for the successful 
transition from academia to the workforce. When all these components are in place, applicants are more appealing and successful in attaining a career after graduation.

While research question 1 highlighted various instances of statistically significant data; conversely, question 2 highlighted one statistically significant analysis. This statically significant analysis arose when male and female respondent's employment outcomes were compared. This is of note because even though all other variables were analyzed (i.e. work-based learning activities and career-related programming) and compared to employment and gender responses, this statistically significant outcome was the only event that arose from all the comparison groups. The analysis indicated that employment outcomes were statistically significant $(\mathrm{p}=096)$, and male respondents had higher levels of employment compared to female respondents even though for this case study, there were more female respondents than males. These results provide insight to the data in question 3 because, question 3 showed that male respondents utilized career readiness programming and informational sessions at higher numbers than their female counterparts. However, female students participated in more work-based learning activities than their male counterparts, which the data shows were more effective towards employment. Therefore, the fact that women utilized work-based learning activities at higher rates than males, but males utilized services that had little to no significant effect on employment is very informative. These results infer that there is a confounding variable that is a barrier to female respondents' employment. This confounding variable 
aligns with the discriminatory practices highlighted in Chapter 2. Discriminatory practices such as hiring manger bias, nepotism and cronyism could be the influential variable that is preventing qualified female applicants from securing employment even though they participated in activities that have been linked to higher employment outcomes.

It was also of note that Chapter 4 did not identify any statistical significance when comparing alumni of color to white alumni across all variables. The absence of statistical significance could be an indication that all SSU alumni felt comfortable, had access and utilized these services equitably. The result could also be an indication that additional data could be needed to properly address the equity issue around the utilization of career preparation services at SSU. As mentioned in Chapter 3, there was an underrepresentation of Latino, Hispanics, and Spanish respondents, and if we had a larger more diverse sample the results may have provided additional insight around this issue.

Another finding from this case study that stood out was the list of confounding variables respondents indicated as main contributors to their employment after graduation.

\section{Confounding Variables}

- Faculty Support

- Educational Opportunity Program

- SSU Academic Departments

- SSU Administrators

- Migrant Ed Advisory Program
- Forums

- SSU Clubs

- Greek Life

- Athletics

- Study Abroad

- Scholars Programs 
- Credential Programs (Teaching, and Nursing)

- Disability Resource Center

- Jump Program

- Residential Life
- Student Government

- TRIO

- Mentorship Program

- 10,000 Degrees (CBO)

These confounding variables although not directly analyzed in the survey are programs and services that reinforce the researcher's hypothesis and theoretical framework. Each of these services and programs have components that support the career identity, personal adaptability, social and human capital of SSU alumni, and thus align with the tents of the Heuristics Model of Employability. Although they are not directly offered by campus career centers, these confounding variables may be a resource for future interdepartmental collaboration and research.

\section{Limitations}

11 CSUs across California were originally interested in participating in this research study but were unable to participate for various reasons. A main reason that the other 10 CSUs were unable to participate was due enlarge to the fact that career centers even though this information would be invaluable to enhance programming indicated that they did not have the resources to store and track alumni data after they exited their programs. These data were often the responsibility of the institution's alumni association, which contributed to the researcher being unable to obtain university approval and participation. In several instances, these CSU Career Centers were interested in participating in this research study, but their Office of Alumni Association informed me 
that they were selective on what surveys they sent to their alumni, and this research study was not a priority for them. They indicated that their correspondences were reserved for Alumni Association related campaigns (i.e. fundraising, donorships, etc.), and they were concerned about survey fatigue. These responses and practices were also being utilized by the Office of Intuitional Effectiveness at some of the CSU campuses as well. If other larger, more diverse, and geographically located CSU campuses were involved in this research study, then the data may have highlighted, supported and/or provided insight to additional areas of best practices and/or deficiencies for SSU and other CSU campuses.

Another limitation of this case study was that the survey did not include any questions regarding SSU's Career Service's Management system. This system stores employer data and provides resources to support the employability of SSU students and alumni. This database was not included in this case study because SSU changed vendors Fall 2018 and implemented their new system Spring 2019. As a result, the alumni surveyed for this case study would have been unable to assess the effectiveness of this new system on employment outcomes.

\section{Implications}

Internships were the most impactful career readiness activity compared to any other career-related service, especially when linked with other career-related programming. Statistical significance was present when internships operated independently, but higher levels of significance occurred when internships were linked with other services. This finding is significant because it aligns with the theory of the Heuristic Model of Employability. In this model, employability is a result of the overlap of the model's main tenets (i.e. career identity, personal adaptability, and social and 
human capital). The overlap of services in this case study (e.g. internships and careerreadiness workshops) resulted in an increase in the statistical significance and employment outcomes (i.e. months to secure full-time employment after graduation) of respondents. This synergistic relationship between all the tenets was most prevalent in the internship and career-readiness workshops groupings, which contributed to these services having the highest significance of all comparison groups $p=.001$. These results are significant for SSU's Career Center because they identify programs and activities that SSU could target and enhance. In addition, this case study provides a theoretical model that could be used to create new programs that impact the employability of graduates.

All CSUs advertise to prospective and current students that degree completion within their institutions increases their employment outcomes, but do not inform them that additional co-curricular career-related activities may not be offered at their respective campuses thus effecting their employment after graduation. This case study reveals the importance of the CSU system ensuring that all their campuses are providing equitable access to work-based learning opportunities and career-related programming that support the employability of their graduates. Programs should provide career-related experiences for their students that align with the tenets of the Heuristic Model of Employability. The data from this case study clearly highlights the importance of career services' programming (i.e. one-on-one advising, career-readiness workshops, advising and career fairs) on the employment outcomes of graduates, especially when more than one service is utilized by students.

Data from this case study also highlights the need for companies to continue to invest more resources needed for additional higher education collaborations especially as 
they relate to work-based learning activities and company outreach/informational sessions. As the research shows, many of the resources that were statistically significant were provided in conjunction with industry partners. These activities and services supported the employment outcomes of SSU alumni, especially length of time needed to secure full-time positions. This is important because employers indicate that they have a difficult time recruiting job ready applicants, but this case study showed that the alumni who utilized services that had an employer internship and other industry related services were able to demonstrate the requisite skills needed for employment. This is evident in the amount of time alumni needed to secure full-time positions compared to their colleagues who did not participate int these services. These data reveal the importance of companies investing more resources needed to support the employability of students. When companies actively assist with the skill development of their future employees, they then increase the pool of qualified applicants needed to alleviate their workforce shortages.

This research also highlights the importance of policies that require institutions to provide adequate support, information and resources needed to ensure employment outcomes of alumni. For example, AB 1803 which did not pass the legislature, would have required a public or private institution of higher education that offers a baccalaureate degree program to provide career placement and job search services to students. In addition, state funds would have been allocated for student financial assistance to provide career placement and job search services to a person for five years after the person receives a baccalaureate degree at the institution, at no cost to the person. Though public and non-profit schools are not held to the same employment reporting 
standard, students attend baccalaureate degree programs, in part, because they believe that education will help them successfully access the workforce. Therefore, if 4-year universities are advertising career mobility for graduates, they must ensure career centers are adequately funded, ensure students have access to resources needed to make them competitive in the job market, and inform students of the importance of career-related cocurricular activities that enhance their employability.

\section{Recommendations for Action}

All CSUs should examine the processes and successful supports alumni have utilized outside of their higher education institutions after they have exited their programs for more than a few months. First-destination surveys are a great resource to determine if students are securing positions immediately after graduation, but there is a rich amount of data that must be collected from alumni who have successfully graduated and continue to work in industry for several years. Those narratives may help universities create new programming that will support the career longevity of their current students.

Furthermore, CSUs should ensure that all students participate in work- based learning and career- readiness activities, in addition to major required courses. Research and this case study have shown that work experience helps students develop a career identity, personal adaptability, social and human capital needed for their employability. Employers have indicated that they value these experiences as much as GPA and degree completion and are unable to find qualified applicants to fill vacant positions.

Lastly, CSUs must address the issues around employment and gender. The results from this study indicate that there may be discriminatory hiring practices occurring at SSU and possibly other CSU for female graduates. CSUs should help support the 
employment of all students and ensure that the companies and employers campuses work with continue to support and utilize best hiring practices. If these companies continue to participate in the exclusionary practices, then CSUs should continue to advocate for our graduates even if that means discontinuing relationships with these companies.

\section{Recommendations for Further Study}

While the research for this study did find some correlations and significance between some career-related services, programming and work-based learning activities, additional research focusing on other services would be recommended. As indicated earlier, an important career service resource that was not included in this research study was SSU's Career Services Management system called Handshake. Career Services Management systems are used to support a career centers' job board, provide online career readiness trainings and tutorials and manage students' career readiness data (i.e. resumes, records, etc.). Career Service Management systems while similar do offer different features depending on the vendor. SSU's Career Service Management System was not included in this research study because SSU recently acquired their new database Spring 2019. For a future research study, I would recommend SSU and other career centers assess the effectiveness of their career services management systems to determine if they do support job attainment, if the features provided by the vendor supported the employability of their students, and if these platforms were more effective than face-toface services, since a lot of colleges utilize the online platforms more than investing in personnel.

Another recommendation for a future study would be to include various CSUs in a similar employment study. As indicated earlier, the selection of additional campuses 
that vary in size, geographical location, and student demographics would help to determine if campus resources are adequately preparing students from different CSUs for the workforce. In addition, campus location does affect the types of industry partnerships educational institutions are able to create. Many rural campuses offer programs that prepare students for jobs in suburban areas. While students exit college with the appropriate degree, many do not have access to internships or career-related workshops that would support entry into certain competitive organizations. Therefore, research that would help urban, suburban and rural CSUs determine best practices that support their student populations employability and provide data that could create equitable access to competitive organizations would support current and future CSU students.

Lastly, analyzing other campus and community-based resources that supported the employability of SSU and CSU alumni would be an important topic to study. Confounding variables that arose from this research centered around community-based organizations and their services; in addition to university related organizations not managed by campus career centers. Researching these variables may create a collaborative system that could impact more students, alleviate costs that prevent new career-related programming from occurring and provide students additional resources that align with the tenets of the Heuristic Model of Employability.

\section{Conclusion}

The California State University system services over 480,000 students annually, and is the largest public university system in the U.S. While the CSU system has created initiatives to support the retention and graduation rates of its students, more work must be done to ensure that all CSU graduates are employable. Degree completion is only one 
component needed to support the employability of graduates. CSUs must ensure that all students have equitable access to career-readiness programming and services that align with the tenets of the Heuristic Model of Employability. The more students utilize these services, the higher the likelihood they will be able to secure full-time employment at higher and quicker rates after graduation. If CSUs want to continue to support graduates' academic and career goals, then all CSU campuses must ensure that their students possess all the requites skills needed for them to continuously navigate the workforce and find their "best fit" careers. 


\section{REFERENCES}

Alfeld, C., Charner, I., Johnson, L. \& Watts, E. (2013). Work-based learning opportunities for high school students. Louisville, KY: National Research Center for Career and Technical Education, University of Louisville.

Arendale, D. (2016). Peer study groups as catalyst for vocational exploration. Research in Developmental Education, 39 (2) 1-26.

Bass, B. (1990). From transactional to transformational leadership: Learning to share the vision. Organizational Dynamics, 19-31.

Becker, G. (1962). Investment in human capital: a theoretical analysis. Journal of Political Economy, 70(9) 9-49.

Bialka, C., \& Havli, S. (2016). Partners in learning: exploring two transformative university and high school service-learning partnerships. Journal of Experiential Education, 39(3) 220-237.

Bourdieu, P. (1986). 'The forms of capital' in J.G. Richardson (ed) Handbook of theory and research for the sociology of education, New York: Greenwood Press, pp. 241-258.

California State University (2018). Retrieved from https://www2.calstate.edu/csusystem/why-the-csu-matters/graduation-initiative-2025

Celio, C. I., Durlak, J., Dymnicki, A. (1993). A meta-analysis of the impact of servicelearning on students. Journal of Experiential Education, 34(2), 164-181.

Channick, R., \& Yerak,B. (2017, April 20). Targeted by Obama, DeVry and other for- 
profit colleges rebounding under Trump. Chicago Tribune.

http://www.chicagotribune.com/business/ct-trump-for-profit-schools-0423-biz20170418-story.html

Coulter, R. (2013). Improving student's understanding of career decision-making through service learning. College Student Journal, 47(2), 306-311.

Dawis, R. V., \& Lofquist, L. H. (1984). A psychological theory of work adjustment. Minneapolis: University of Minnesota Press.

Dupre, C., Williams, K. (2011). Undergraduates' perception of employer expectations. Journal of Career and Technical Education, 26(1), 8-19.

Ellis, M., Kisling., \& Hackworth, R. (2014). Teaching soft skills employers need. Community College Journal of Research and Practice, 38, 433-453.

Esters, L.T., \& Retallick, M.S. (2013). Effect of an experiential and work-based learning program on vocational identity, career decision self- efficacy and career maturity. Career and Technical Education Research, 38(1), 69-83.

Gomez-Lanier, L. (2016). The effects of an experiential service-learning project on residential interior design students' attitudes toward design and community. International Journal for the Scholarship of Teaching and Learning, 10(2), 1-7.

Grover, K. (2014). Experiential learning and its role in training and improved practice in high level sports officiating. Journal of Research in Education, 24(2), 1-13.

Hadassah, L., Vered, L., \& Benjamin, B. (2014). Strengths-based career counseling: overview and initial evaluation. Journal of Career Assessment, 22(3), 403-419.

Higher Education Research Institute (2016). Retrieved from http://newsroom.ucla.edu/releases/heri-freshman-survey-242619 
Huff, J., Zoltowski, C., \& Oakes, W. (2016). Preparing engineers for the workplace through service learning: perceptions of EPICS alumni. Journal of Engineering Education 105(1), 43-69.

Karp, M. \& Bork, R. (2014). They never told me what to expect, so I didn't know. Defining and clarifying the role of a community college student. Teachers College Record, 1-23.

Knowles, M. (1975). Self-directed learning: A guide for learners and teachers. Chicago: Follett Publishing Company.

Kraebber, S.L, Greenan, J, P. (2012). The relationship between self-concept and selfrating of generalizable skills of students in postsecondary career and technical programs. Journal of Career and Technical Education, 27(1), 15-33.

Leung, A. (2008). The big five career theories. International Handbook of Career Guidance, 115-132.

Leonhardt, D. (2014, May 29). The jobless rate for community-college graduates is also low. The New York Times. Retrieved from https://www.nvtimes.com/2014/05/29/upshot/the-jobless-rate-for-communitycollege-graduates-is-also-low.html.

McKinsey \& Company (2012). Retrieved from https://www.mckinsev.com/industries/social-sector/our-insights/education-toemployment-designing-a-system-that-works

Morgan, L. (2014). School counselors' perceptions of competency in career counseling. Professional Counselor, 4(5), 481-496. 
National Association of Colleges and Employers (2017). Job Outlook. Retrieved from http://file://C:/Users/citym/Desktop/EDDL\%20962/962\%20paper\%202/2017nace-job-outlook-full-report\%20(1).pdf

Nauta, M. (2010). The development, evolution, and status of holland's theory of vocational

personalities: reflection and future directions for counseling psychology. Journal of Counseling Psychology, 57(1), 11-22

Nunez, A.-M. (2016). Earning and learning: exploring the meaning of work in the experiences of first-generation Latino college students. The Review of Higher Education, (40)1, 91-116.

Payne, K.\& Sumter, M., (2005). College students' perceptions about career fairs: what they Like, what they gain, and what they want to see. College Student Journal (39)2, 269

Peterson, R., \& Dover, H. (2014). Building student networks with linkedin: the potential for connections, internships, and jobs. Marketing Education Review (24)1, 15-20.

Putnam, R. D., (1993). The prosperous community. The American Prospect, 4(13), 3542.

Robles, M. (2012). Executive perceptions of the top 10 soft skills needed in today's workplace. Business Communication Quarterly, 75(4), 453-465.

Rivera, L. A. (2012). Hiring as cultural matching the case of elite professional service firms. American Sociological Review, 77(6), 999-1022.

Rivera, L. A. (2015) Pedigree: Elite reproduction in hiring. Princeton, NJ: Princeton University Press. 
Super, D. E. (1953). A theory of vocational development. American Psychologist, 8(5), 185-190.

Starda-Gallup (2017). Retrieved from http://stradaeducation.gallup.com/reports/225161/2017-strada-gallup-collegestudentsurvey.aspx?utm_source=link_newsv9\&utm_campaign=item_225446\&utm_medi um=coy

Teaching Excellence in Adult Literacy (2012). Retrieved from https:/lincs.ed.gov/programs/teal/guide/adultlearning

Verbruggen, M., \& Sels, L. (2010). Social-cognitive factors affecting clients' career and life satisfaction after counseling. Journal of Career Assessment. 18(1), 3-15. 


\section{Appendix A.}

\section{APPENDIX}

Handshake Questionnaire

Student Information

1. Primary Concentration

2. Undergraduate Major

3. Graduate Degree

- MBA

- Full-time

- Part-time

- Specialty Masters

4. Are you authorized to work in the U.S.?

- Yes

- No

5. Personal Email Address

Graduation Status

1. (If Selected Full-Time) What is your status at graduation?

- I am NOT looking for a job

- I am looking for a job

- I have received a job offer

2. (If selected Part-Time) What is your status at graduation?

- Employed

- Started/Starting Own Business

- Unemployed

- Left the Workforce

Not Seeking or Unemployed

1. What are you primarily doing after graduation?
- Volunteering
- Military
- Company Sponsored or Already Employed
- Starting a New Business as an Owner/Founder
- Postponing Job Search
- Not seeking for Other Reasons 


\section{Volunteering}

1. Which organization are you volunteering for?

- Name of organization

2. What city is this position located in?

- Select a city

3. What is your job title?

4. What is your job function?

5. When did you get this offer?

○ yyyy-mm-dd

6. When did you accept it?

o yyyy-mm-dd

7. When is your start date?

o yyyy-mm-dd

\section{Continuing Education}

1. What's the name of the institution?

2. What city is this institution located in?

3. What's your program of study?

4. What's the degree you're pursuing?

- (Dropdown) Associates, Bachelors, Masters, Doctorate, Postdoctoral Studies

Military

1. Which service branch are you joining?

- Air Force, Army, Coast Guard, Navy, Marine Corps

2. Enlisted, Warrant Officer, Officer

3. What city is this position located in?

4. What is your specialization? (not required)

5. Base Salary

- Monthly Stipend

- Hourly Wage

- Annual Salary

6. When did you get this offer?

○ yyyy-mm-dd

7. When did you accept it?

- yyyy-mm-dd

8. When is your start date?

- Yyyy-mm-dd 


\section{Company Sponsored or Already Employed}

1. Who is your employer?

2. What industry is your employer in?

- (Dropdown) MBACSEA industry list

3. What city is this position located in?

\section{Starting a New Business as an Owner/Founder}

1. Who is your employer?

2. What industry is your employer in?

- (Dropdown) MBACSEA industry list

3. What city is this position located in?

\section{Offer Details}

1. What is the status of your job offer?
- Accepted
- Rejected
- Pending

2. What date did you receive this offer?

\section{Employer Details}

1. Who is the employer who extended this offer?

2. What industry is your employer in?

- (Dropdown) MBACSEA industry list

3. What city is this position located in?

\section{Job Details}

1. How many hours per week are you working?

- Over 30 Hours a week

- Under 30 Hours a week

2. What is your job title?

3. Were you already working in this position during school? 
- Yes

- No

4. What date did you accept this offer?

5. What is your job function?

- (Dropdown) MBACSEA job functions

\section{Salary Details}

1. How are you compensated?

2. Under how are you compensated?

- Monthly Stipend

- Hourly Wage

- Annual Salary

3. Does your employer have a bonus structure?

- Yes

- No

4. What is the amount of your signing bonus in U.S. dollars?

\section{Job Source}

1. Do you believe that school facilitated or graduate facilitated activities helped prepare you most for the accepted job offer?

- School facilitated

- Conversion of internship; internship obtained through school sources

- Scheduled interviews on or off campus for full-time employment

- Job postings on school career systems, resume books, resume referrals by career centers

- Activities supported by the career center (i.e. job fairs/conf,employer events,school promoted job boards)

- Graduate facilitated

- Conversion of internship;internship obtained through graduate-initiated sources

- Personal contacts (i.e. previous employers, family, friends outside of school)

- Online job postings (i.e. social media/Linkedln, Indeed, Company websites)

- Other graduate facilitated source 


\section{Appendix B.}

\section{CTEOS Survey}

\section{CTEOS 2019}

Greetings from $<$ CollegeName $>,<$ FirstName $>$. Our records indicate you were taking classes in the 2016-2017 year. In order to improve our services, we would like to ask you for some feedback. This survey is confidential -- no identifying information will be used in any reports. More information about this survey can be found at cteos.santarosa.edu. Thank you very much!

How satisfied are you with the education and training you received at $<$ CollegeName $>$ Very Satisfied Satisfied Neither Satisfied

nor Dissatisfied Dissatisfied Very Dissatisfied

Please explain the main reason you were Satisfied/Dissatisfied with your education and training: 
was the one PRIMARY reason you studied at $<$ CollegeName $>$ ?

Earn a certificate or degree AND transfer

Earn a certificate or degree NOT to transfer

Earn transfer units with or without getting an

Associate degree Take classes to update

job skills or renew a license/permit Take

classes for self-enrichment only Other:

What program of study (certificate, or major) were you pursuing at our college?

None (N/A) Accounting Business

Child Development/Early Childhood 
Education (ECE) Computer Science

Criminal Justice / Administration of Justice

Dental Hygiene/Assisting Graphic

Design Interior Design Nursing

Paralegal Real Estate

Other

Please identify your program of study here:

It appears that you are not taking as many classes at our college as you

have in the past. Please tell us why. Mark all that apply. My goals were met

I completed the program 
Didn't have enough time for classes

I got a job

My job changed

Relocation

Classes I needed were not available

Family or

personal reasons

Transferred to another

school 
Financial reasons

I stopped attending for a while but then I returned

Other, please explain

Did

you use Career Services offered at our college?

Yes - many times $\quad$ Yes - once or a few times

No - not at all

As part of your coursework or training at our college, did you participate in an internship or other formal work-based learning opportunity? No 


$$
\begin{aligned}
& \text { Yes - paid } \\
& \text { Yes - unpaid }
\end{aligned}
$$

As part of your coursework or training at our college, did you participate in an

$$
\text { Apprenticeship? Yes }
$$

No

Name of apprenticeship program:

completing your coursework, did you transfer to another college or university? No, I

did not transfer $\bigcirc$ Yes, I transferred to a different college, IN THE SAME FIELD OF

STUDY Yes, I transferred to a different college, IN A DIFFERENT FIELD OF

STUDY 
Name of transfer college or university?

Was this a two-year or four-year college or university?

Two-year college Four-year college or university Other:

After completing your coursework, did you do any of the following? (Check all that apply) I obtained an official industry certification or state/professional license in the same field of study (not a college-awarded certificate)

Name of certification or license: 
I obtained official certification of journey-level status in the same field of

study

Name of certification of journey-level status:

What was the main impact that your coursework had on your

employment? Allowed me to stay in my current job

Allowed me to get a promotion at my same organization Allowed me to get a

job at a new organization Allowed me to start my own business

Prepared me for a possible new job No impact on my employment

Other, please explain: 
best describes your current employment status?

Self-Employed Employed at one job Employed at more than one job

Working, but not for pay (care giving, volunteer, etc.) and not seeking paid employment Working, but not for pay, and seeking paid employment

Unemployed, seeking employment

Unemployed, not seeking employment

Did you engage in a job search after you finished your courses and training? Yes, and I found a job Yes, and I still have not found a job

No, I was already employed when I finished my courses and training No, I was not looking for employment after I finished my courses and training Not applicable as I am still pursuing my studies 
How long (in months) did it take you to find a job?

0 months (I found one by the time I finished school) $\quad 1-3$ months $\quad 4-6$

months 7-12 months

$13+$ months

Were you employed BEFORE you took classes at our college?

Yes No

Before your coursework, were you employed:

Full time at one job (40 or more hours per

week) Part time job or jobs (20 or more

hours per week)

Part time job or jobs (less than 20 hours per week)

Before your coursework, was your employment: 
Permanent Temporary

Seasonal

What

was the average hourly wage of your employment before your coursework? (If you were salaried, please convert to hourly wage -- for a full time job, divide annual salary by 2,000.)

What is your current job title?

Which industry is your current job in?

Agriculture, Forestry, Fishing and

Hunting

Accommodation and Food Services (e.g., restaurant server, bartender)

Administrative and Support and Waste Management and Remediation Services 
(e.g., security guard) Arts, Entertainment, and Recreation Construction

Educational Services (e.g., teacher, tutor) Finance and Insurance

Health Care and Social Assistance (e.g., dental hygienist, nurse, counselor, radiologic technologist, patient service representative, child daycare)

Information (e.g., library services) Management of Companies and

Enterprises Manufacturing Mining Professional, Scientific, and

Technical Services (e.g., veterinary technician, accountant, paralegal, legal

assistant, interior design, graphic design, tax professional)

Public Administration (court operations clerk, firefighter, police or correctional officer)

Real Estate Rental and Leasing (e.g., real estate agent or broker) Retail Trade

(e.g., pharmacy technician, retail associate) Transportation and Warehousing

(e.g., limousine driver, truck driver) - Utilities Wholesale Trade

Other 
How closely related to your field of study is your current job?

Very close -- my current job is in the same field as my coursework and training Close -- I used what I learned in my coursework and training even though I am not working in the exact same field

Not close -- my coursework and training are not at all related to my current job

Is your current employment: Full time at one

job (40 or more hours per week) Part time

job or jobs (20 or more hours per week)

Part time job or jobs (less than 20 hours per

week)

Is your current

employment: 


\section{Permanent}

\section{Temporary}

Seasonal

What is the average hourly wage of your current employment? (If you are salaried, please convert to hourly wage -- for a full time job, divide salary by 2,000 .)

What is the 5-digit ZIP code of your current employment?

How long have you been in your current employment? less than 6 months 6 
months to 1 year $\bigcirc-2$ years $\bigcirc 2-3$

years

3 or more years

If you are currently employed, are you actively seeking a job in a different field? Yes

No

Thank you for taking the CTE Outcomes Survey. More information about this survey can be found at cteos.santarosa.edu 
Appendix C.

\section{Dissertation Survey \\ Education to Employment Pipeline}

Greetings!

Thank you for agreeing to take part in this important survey measuring Sonoma State

University's career-readiness programming, and the effect (if any) it had on your employability after your graduation.

This survey is confidential, and no identifying information will be used in any reports.

This survey should only take 5-7 minutes to complete. Please click "Next" to begin. 


\section{Informed Consent to Participate in Research}

\section{PURPOSE AND BACKGROUND}

The purpose of this research is to determine the effectiveness of Sonoma State University's (SSU) career-readiness programming and services. Participant's responses will be used to help guide current and future career-readiness programming, and ensure the continued career success of SSU students and alumni.

The researcher is a graduate student from San Francisco State University (SFSU) conducting research for a doctoral degree from SFSU's Educational Leadership program.

\section{PROCEDURES}

If you agree to participate in this research, the following will occur: you will be asked a series of question to assess the effectiveness of Sonoma State's career-readiness programming and services ( total time commitment shouldn't be longer than 10 minutes).

\section{RISKS}

No names or identities will be used in any published reports of the research. Only the researcher will have access to the research data. 


\section{CONFIDENTIALITY}

The research data will be kept in a secure location and only the researcher will have access to the data. All research data will be stored in an encrypted document on a password protected computer.

\section{DIRECT BENEFITS}

There will be no direct benefits to the participant.

\section{COSTS}

There will be no costs for participating in this research.

\section{COMPENSATION}

Three participants will be selected at random to receive a $\$ 20$ Amazon Gift Card.

\section{ALTERNATIVES}

The alternative is not to participate in the research.

\section{QUESTIONS}

If you have any further questions about the study, you may contact the researcher by 
email at: ajones7@mail.sfsu.edu

\section{CONSENT}

PARTICIPATION IN THIS RESEARCH IS VOLUNTARY. You are free to decline to participate in this research, or to withdraw your participation at any point, without penalty.

Please continue if you would like to participate in this study, and include your name in the \$20 Amazon Gift Card drawing.

\section{Emplovment Status:}

The questions in this section were designed to identify the employment outcomes of Sonoma State alumni after their graduation/degree attainment. 
About how many months did it take you to secure full-time employment after your graduation?

I accepted a full-time job offer (before graduation), and continued to work with that company (after graduation). (2)

If you obtained full-time employment AFTER GRADUATION, how many MONTHS did it take you to obtain this full-time position? (1)

I have not obtained full-time employment since my graduation from Sonoma State University. (4) 
How closely related to your field of study was your first full-time job after graduation?

Very close - (The job was in the same field as my coursework and training). (1)

Close- (I utilized my coursework and training in this role, but the job resided in another field). (2)

Not close- (My coursework and training were not related to this job). (3)

Was your first full-time job after graduation within 25 miles of Sonoma State University?

Yes (please indicate location) (1)

No (please indicate location) (2) 
How long did you remain in your first full-time job after graduation?

less than 1 year (1)

$1-2$ years $(2)$

$2-3$ years $(3)$

3 or more years (4)

What industry closely aligns with your first full-time job after graduation (e.g. business, engineering, etc.)?

What was the job title for your first full-time job after graduation? 
Did you attend graduate school immediately after graduation?

Yes (1)

No (2)

University Programming/ Activities: These next questions ask you about the helpfulness of various career readiness programming that were available at Sonoma State University while you were a student. For each statement, please select the response that best matches your view. 
Q38 One-on-one meetings with Sonoma State faculty advisors and/or career center personnel were helpful to me.

Strongly Agree (1)

Agree (2)

Neither agree of disagree (3)

Disagree (4)

Strongly Disagree (5)

I did not meet with any faculty advisors and/or career center personnel. (6) 
Sonoma State's career fairs were helpful to me. (Career Fairs refer to events where multiple companies, government agencies, and or non-profit organizations inform and recruit students for various positions within their organization).

Strongly Agree (1)

Agree (2)

Neither agree nor disagree (3)

Disagree (4)

Strongly disagree (5)

I did not participate in Sonoma State's career fairs. (6)

Sonoma State's industry informational sessions were helpful to me. (Informational sessions refer to small networking opportunities (usually a single 
company at a time), where students learn about the company/organization and what employment opportunities are available).

Strongly Agree (1)

Agree (2)

Neither agree nor disagree (3)

Disagree (4)

Strongly disagree (5)

I did not participate in Sonoma State's informational sessions. (6)

Sonoma State's career-readiness workshops helped prepare me for post graduate employment.

(Career-readiness workshops refer to sessions that help attendees navigate the job 
search process. Common topics include resume critiques, mock interviewing, application assistance, etc.).

Strongly Agree (1)

Agree (2)

Neither agree nor disagree (3)

Disagree (4)

Strongly Disagree (5)

I did not participate in any career-readiness workshops. (6)

Internships, Service Learning and Employment:

This next section asks you about work-based learning opportunities (i.e. internships, service-learning, and other employment), and if they contributed to 
your skill development and employment.

Did you participate in any internships while you were a student?

Internships refer to temporary structured work experience opportunities related to a student's major and/or career goal).

Yes (1)

No (2) 
Participation in internship opportunities provided me the hard skills (i.e. technical skills) needed for employment after graduation.

Strongly Agree (1)

Agree (2)

Neither agree nor disagree (3)

Disagree (4)

Strongly disagree (5) 
Participation in internship opportunities provided me the soft skills (e.g. problem-solving skills, communication skills, leadership, work ethic, etc.) needed for employment after graduation.

Strongly Agree (1)

Agree (2)

Neither agree nor disagree (3)

Disagree (4)

Strongly disagree (5)

After graduation, I accepted a full-time employment position from my internship site.

Yes (1)

No (2) 
Did you participate in any service- learning opportunities while you were a student?

(Service-learning refers to temporary work experience that provide meaningful community service usually linked with curricular instruction).

\section{Yes (1)}

No (2) 
Participation in service-learning opportunities provided me the hard skills (i.e. technical skills) needed for employment after graduation.

Strongly Agree (1)

Agree (2)

Neither agree nor disagree (3)

Disagree (4)

Strongly disagree (5) 
Participation in service-learning opportunities provided me the soft skills (e.g. problem-solving skills, communication skills, leadership, work ethic, etc.) needed for employment after graduation.

Strongly Agree (1)

Agree (2)

Neither agree nor disagree (3)

Disagree (4)

Strongly disagree (5)

After graduation, I accepted a full-time employment position from my servicelearning site.

Yes (1)

No (2) 
Did you participate in any employment opportunities while you were a student? (Employment opportunities refer to part-time and/or full-time work with a company).

Yes (1)

No (2)

Participation in employment opportunities provided me the hard skills (i.e. technical skills) needed for employment after graduation.

Strongly Agree (1)

Agree (2)

Neither agree nor disagree (3)

Disagree (4)

Strongly disagree (5) 
Participation in employment opportunities provided me the soft skills (e.g. problem-solving skills, communication skills, leadership, work ethic, etc.) needed for employment after graduation.

Strongly Agree (1)

Agree (2)

Neither agree nor disagree (3)

Disagree (4)

Strongly disagree (5)

After graduation, I accepted a full-time employment position with my full-time/ part-time employer.

Yes (1)

No (2) 


\section{Alumni Engagement:}

This section was designed to determine if Sonoma State's Alumni Association provided alumni-related services and resources.

Have you connected with Sonoma State University's Alumni Association?

Yes (1)

No (2) 
Sonoma State's Alumni Association helped connect me with a mentor, networking event, and/or resource(s) that contributed to my employment after graduation.

Strongly Agree (1)

Agree (2)

Neither agree nor disagree (3)

Disagree (4)

Strongly disagree (5)

Did any other Sonoma State University services contribute to your employment after graduation (please specify)? 
Participant Demographics: What program of study (major) were you pursuing at your institution?

Please indicate your graduation year:

$2018(2)$

$2017(3)$

$2016(4)$

$2015(5)$

$2014(7)$ 
Please indicate your gender:

Male (1)

Female (2)

Other (specify) (3) 
How do you describe your ethnicity?

\section{(Check all that apply)}

American Indian or Alaska Native (1)

Asian (2)

Black or African American (3)

Middle Eastern or North African (4)

Native Hawaiian or Other Pacific Islander (5)

Hispanic, Latino(a), or Spanish (6)

White (7)

Other/Prefer to self-describe (8) 
Thank you for taking time to complete this survey!

Please enter vour email below if you'd like to be included in the (\$20 Amazon Gift Card) drawing.

We will be selecting three participants at random, and the three winners will be emailed their \$20 Amazon Gift Card by 6/1/2019. 